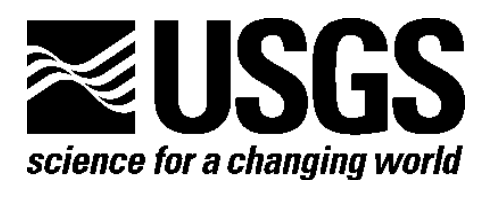

\title{
Quick-Start Guide for Version 3.0 of EMINERS- Economic Mineral Resource Simulator
}

By Walter J. Bawiec and Gregory T. Spanski

A supplement to USGS Open-File Report 2004-1344, Version 3.0 of EMINERS-

Economic Mineral Resource Simulator, by J.S. Duval

Open-File Report 2009-1057

First released June 2012

U.S. Department of the Interior

U.S. Geological Survey 


\section{U.S. Department of the Interior \\ KEN SALAZAR, Secretary}

\section{U.S. Geological Survey \\ Marcia K. McNutt, Director}

U.S. Geological Survey, Reston, Virginia: 2012

For more information on the USGS—-the Federal source for science about the Earth, its natural and living resources, natural hazards, and the environment-visit

http://www.usgs.gov or call 1-888-ASK-USGS

For an overview of USGS information products, including maps, imagery, and publications, visit http://www.usgs.gov/pubprod

To order this and other USGS information products, visit http://store.usgs.gov

Suggested citation:

Bawiec, W.J., and Spanski, G.T., 2012, Quick-start guide for version 3.0 of EMINERS-Economic Mineral Resource Simulator: U.S. Geological Survey Open-File Report 2009-1057, 26 p., available only at http://pubs.usgs.gov/of/2009/1057. (This report supplements USGS OFR 2004-1344.).

Any use of trade, product, or firm names is for descriptive purposes only and does not imply endorsement by the U.S. Government.

Although this report is in the public domain, permission must be secured from the individual copyright owners to reproduce any copyrighted material contained within this report. 


\section{Contents}

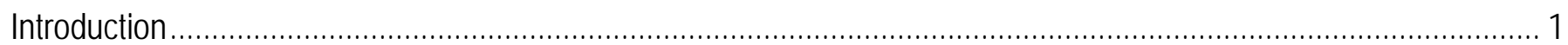

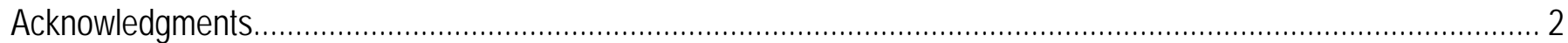

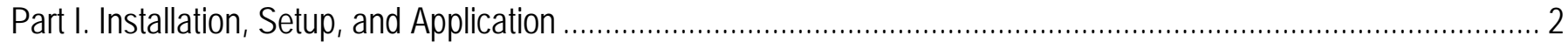

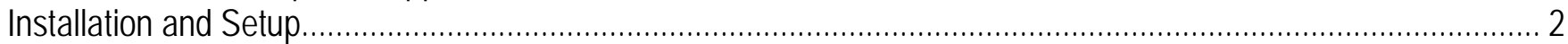

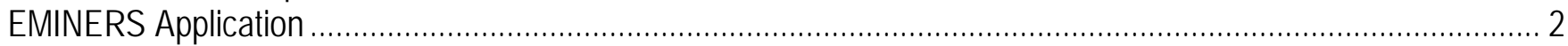

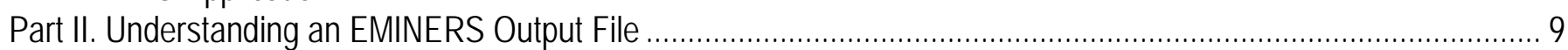

Part III. Creation of Tables and Graphs by Use of Excel Templates......................................................... 13

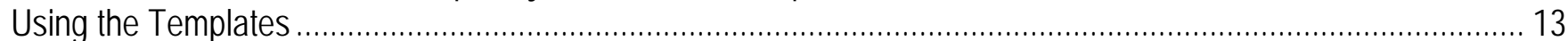

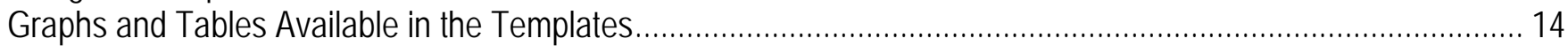

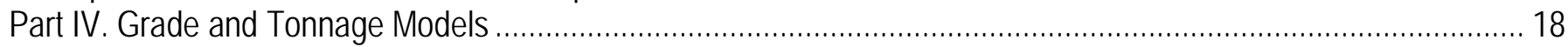

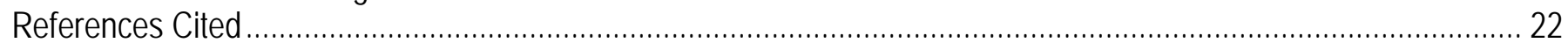

\section{Table}

1. Listing of EMINERS model numbers, model names, commodities present, recommended template to use, and model sources. 


\title{
Quick-Start Guide for Version 3.0 of EMINERS- Economic Mineral Resource Simulator
}

\author{
By Walter J. Bawiec and Gregory T. Spanski
}

\section{Introduction}

Quantitative mineral resource assessment, as developed by the U.S. Geological Survey (USGS), consists of three parts: (1) development of grade and tonnage mineral deposit models; (2) delineation of tracts permissive for each deposit type; and (3) probabilistic estimation of the numbers of undiscovered deposits for each deposit type (Singer and Menzie, 2010). The estimate of the number of undiscovered deposits at different levels of probability is the input to the EMINERS (Economic Mineral Resource Simulator) program.

EMINERS uses a Monte Carlo statistical process to combine probabilistic estimates of undiscovered mineral deposits with models of mineral deposit grade and tonnage to estimate mineral resources. It is based upon a simulation program developed by Root and others (1992), who discussed many of the methods and algorithms of the program. Various versions of the original program (called "MARK3" and developed by David H. Root, William A. Scott, and Lawrence J. Drew of the USGS) have been published (Root, Scott, and Selner, 1996; Duval, 2000, 2012).

The current version (3.0) of the EMINERS program is available as USGS Open-File Report 2004-1344 (Duval, 2012). Changes from version 2.0 include updating 87 grade and tonnage models, designing new templates to produce graphs showing cumulative distribution and summary tables, and disabling economic filters. The economic filters were disabled because embedded data for costs of labor and materials, mining techniques, and beneficiation methods are out of date. However, the cost algorithms used in the disabled economic filters are still in the program and available for reference for mining methods and milling techniques included in Camm (1991).

EMINERS is written in $\mathrm{C}++$ and depends upon the Microsoft Visual $\mathrm{C}++6.0$ programming environment. The code depends heavily on the use of Microsoft Foundation Classes (MFC) for implementation of the Windows interface. The program works only on Microsoft Windows XP or newer personal computers. It does not work on Macintosh computers.

This report demonstrates how to execute EMINERS software using default settings and existing deposit models. Many options are available when setting up the simulation. Information and explanations addressing these optional parameters can be found in the EMINERS Help files. Help files are available during execution of EMINERS by selecting EMINERS Help from the pull-down menu under Help on the EMINERS menu bar.

There are four sections in this report. Part I describes the installation, setup, and application of the EMINERS program, and Part II illustrates how to interpret the text file that is produced. Part III describes the creation of tables and graphs by use of the provided Excel templates. Part IV summarizes grade and tonnage models used in version 3.0 of EMINERS. 


\section{Acknowledgments}

The authors thank USGS colleagues Michael L. Zientek and Mark J. Mihalasky for their insightful technical reviews of this manuscript and Peter N. Schweitzer for his help in understanding the code of this program.

\section{Part I. Installation, Setup, and Application}

\section{Installation and Setup}

The EMINERS program can be used only on a Windows-based platform.

1. Copy the file EMINERS.zip to a folder on your computer where the EMINERS program will reside.

2. Unzip the EMINERS.zip file.

3. If the unzip process does not create a subfolder under EMINERS called EMINERS Output, create that folder.

\section{EMINERS Application}

To execute EMINERS, double click on the file EMINERS.EXE to launch the application. When this program is executed for the first time or when the locations of the EMINERS program and files are unfamiliar (for example, they are running from a compact disc), a window stating, "Unable to open EMINERS initialization file!” will appear.

1. Click OK.

2. The window “Please locate the EMINERS configuration file (ModlData.txt)" appears. Navigate to the disk drive and then to the folder that contains the EMINERS configuration file (ModIData.txt). This step is necessary because the user may have copied these program files to various disk drives and file locations.

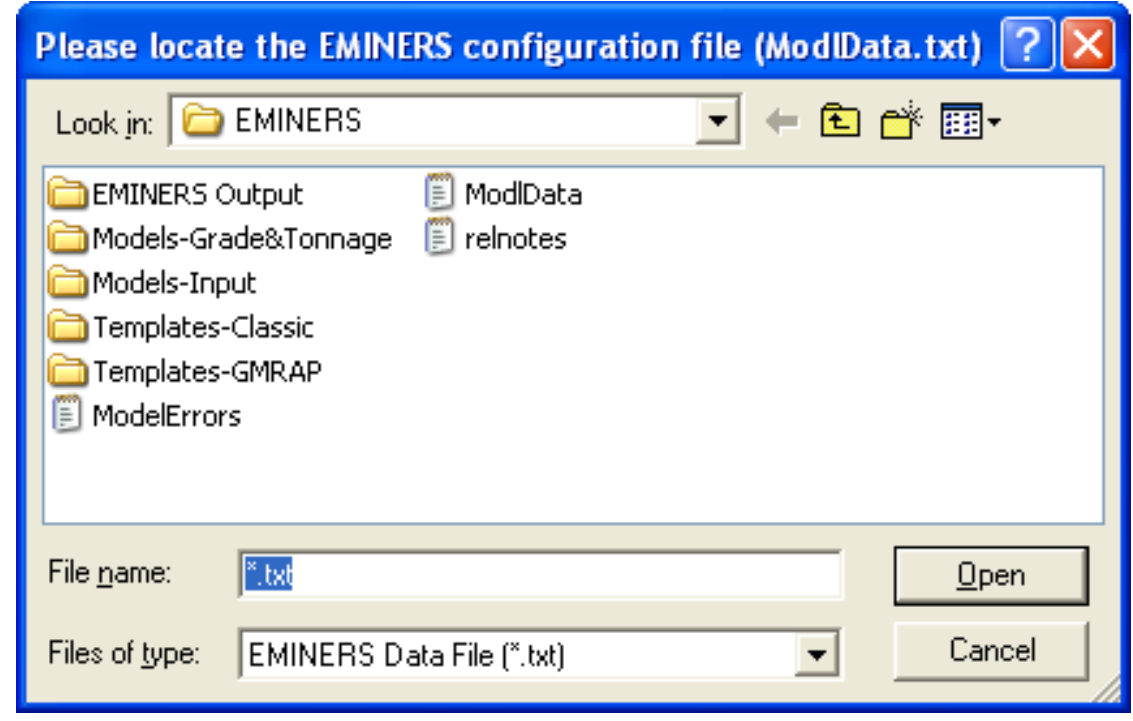

3. Select ModIData.txt and click Open to open the file. The window "EMINERS - Eminer1" opens. This window may be enlarged by dragging its corners. The window provides information on how to start using the program. 


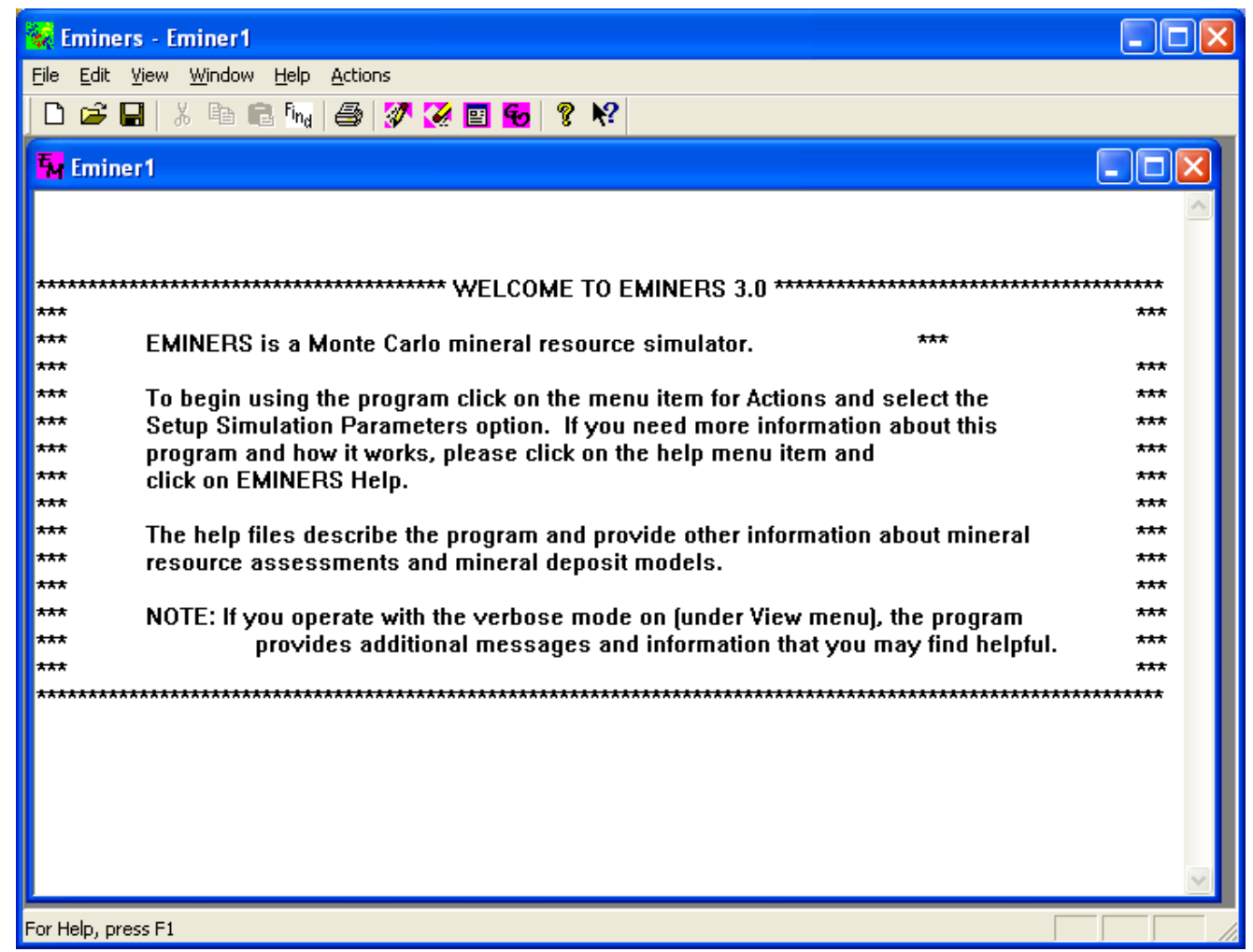

4. Under Actions in the menu bar in the window "Eminers - Eminers1," select the option Setup Simulation Parameters from the pull-down menu.

5. The window “Initial Data for Mark3” opens:

\begin{tabular}{|c|c|}
\hline \multicolumn{2}{|l|}{ Initial Data for Mark3 } \\
\hline Enter your name here $\Rightarrow$ & USGS \\
\hline Name of the Assessment Area $\Rightarrow$ & 142pCu7001 \\
\hline How many models are to be run? & 1 \\
\hline Choose which type of total you want - & \\
\hline Calculate Tract Totals $\Gamma$ & Calculate the Grand Total $\sqrt{\checkmark}$ \\
\hline
\end{tabular}

Provide Special Format Output With Histogram $\sqrt{\checkmark}$ Include Standard Format Output $\sqrt{\checkmark}$ Include Comma-Separated-Value (CSV) Format $\Gamma$ Provide Axum script and data files $\Gamma$ Provide Special Format for each Model?

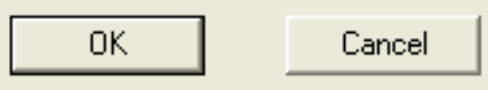


a. Enter your name in Enter your name here $=>$ box. This name will appear in the EMINERS output table.

b. Enter the name of the assessment tract in Name of the Assessment Area=> box. The name may contain as many as 50 alphanumeric characters, although fewer are recommended because this information is used in output file names. Blank spaces, commas, or other special characters should NOT be used in assessment area names because their use can cause errors when the output files are created.

c. Enter a numeric value in How many models are to be run? box. If you are running EMINERS for a single deposit model, enter the number 1 or strike the TAB key to move to the next field. The output will produce results that can be incorporated into the Excel templates for graphs and tables. However, if more than one model is calculated per tract, or more than one tract is calculated and aggregated, while the EMINERS results for metal endowment are correct (assuming complete dependence), they are not in the proper format to be displayed in the Excel templates to create graphs and tables.

d. Choose which type of total you want. The default setting is Calculate the Grand Total. This will provide the proper format for the Excel templates.

e. Select the types of formats you want produced. Default settings are Include Standard Format Output and Provide Special Format for each Model. Information related to each of these output formats can be found by doing the following steps ${ }^{1}$ :

1. Click on Help in the menu bar.

2. Select EMINERS Help.

3. Click on the Find TAB.

4. Search for the word "format."

5. Click on the format of interest in the topics list.

6. Click on Display.

f. Check the box next to Provide Special Format Output With Histogram. Including this option creates a CSV file that can be used with the Microsoft Excel templates to produce the tables and graphs for reports and presentations described in "Part III. Creation of Tables and Graphs by Use of Excel Templates."

g. Click OK.

6. The window "Select the first deposit model." opens:

a. Select the model you wish to use from this pull-down list.

\footnotetext{
${ }^{1}$ To use the Help files provided with EMINERS, users of Windows Vista and beyond (including Windows 7, Windows Server 2008, Windows Server 2008 R2, and any version of Windows 8) must obtain and install the Windows Help program (WinHlp32.exe) appropriate to their operating systems. Microsoft support describes the reasons and necessary steps here: http://suppport.microsoft.com/kb/917607 (accessed March 23, 2012).
} 


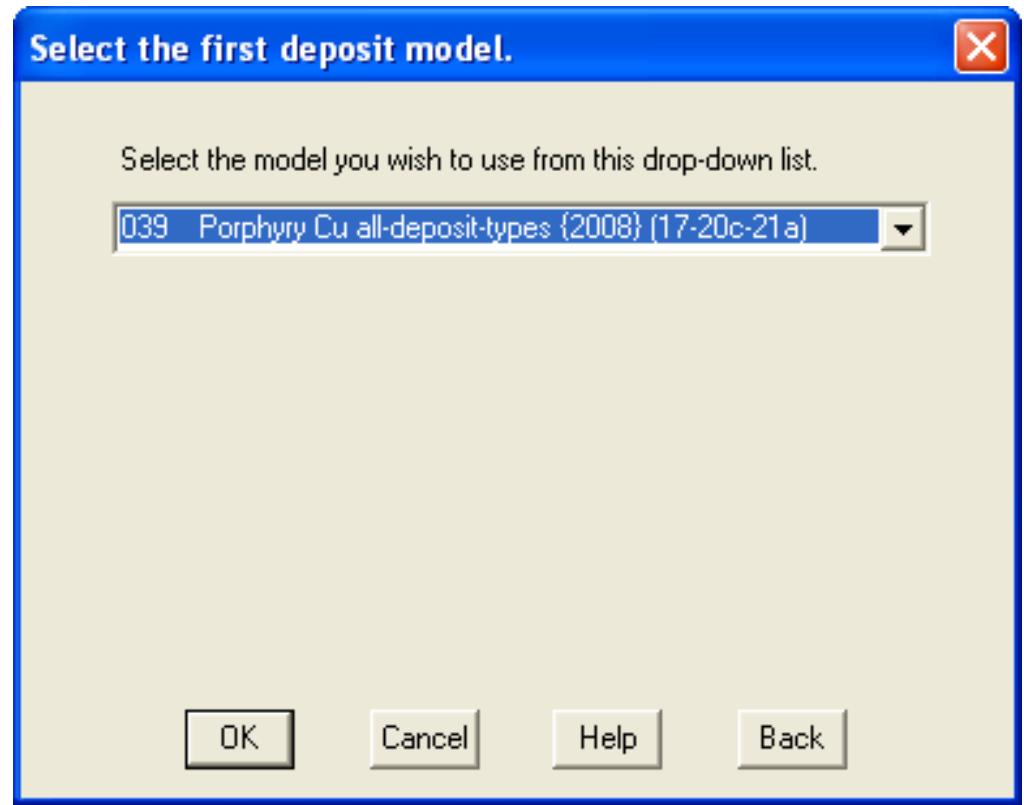

b. Click OK.

7. The window “Select the Type of Probability Function, Code Name, Probability Gro...” opens:

\section{Select the Type of Probability Function, Code Name, Probability Gro... X}

039 Porphyry Cu all-deposit-types $\{2008\}$ (17-20c-21a) 422-* Model039

Enter a Code Name Here [4 Characters] QQ01

Pick Function Type-
$\Gamma$ Lognormal
$\sqrt{\checkmark}$ Empirica:

- Set Number of Probability Levels

$\sqrt{\checkmark}$ Use 3 Levels

Г Use 5 Levels

Г Use 9 Levels

\begin{tabular}{|l|l|l|l|l|}
\hline Cancel \\
\hline
\end{tabular}

a. Enter a Code Name Here is a dummy variable field that can be used for tracking separate runs; it appears in the EMINERS output and does not need to be replaced.

b. Pick Function Type; the default setting is Empirical. Use EMINERS Help, Find for more information.

c. Check the appropriate value for Set Number of Probability Levels; for USGS studies, this number is determined by the assessment team doing the quantitative assessment.

d. Click OK.

8. The window "Estimate Number of Deposits" opens: 
Enter the estimated number of deposits for each of the confidence levels given below.

$$
\begin{array}{l|l}
90 \text { Percent Level } & 0 \\
50 \text { Percent Level } & 2 \\
10 \text { Percent Level } & 6
\end{array}
$$

What is the Probability of Zero Deposits?

The default value of -1 causes EMINERS

to calculate a value for you

\begin{tabular}{|l|l|l|l|l|l|l}
\hline Cancel Help \\
\hline
\end{tabular}

a. Enter an integer value for each level; you can use the TAB key to move through all data entry fields. Click on the Help button for more information.

b. In most cases, accept the default value of -1 in the What is the Probability of Zero Deposits? box. The value of -1 allows the program to calculate the default probability of zero deposits. This calculation is dependent upon the input distribution and results in a nonzero value for the probability of zero deposits. If you are unsure about this option, enter a value of -1 and allow the program to calculate the probability of zero deposits.

\section{c. Click OK.}

9. The window “Open" appears. At this point, the location of the grade and tonnage input files in the Models-Input folder must be identified.

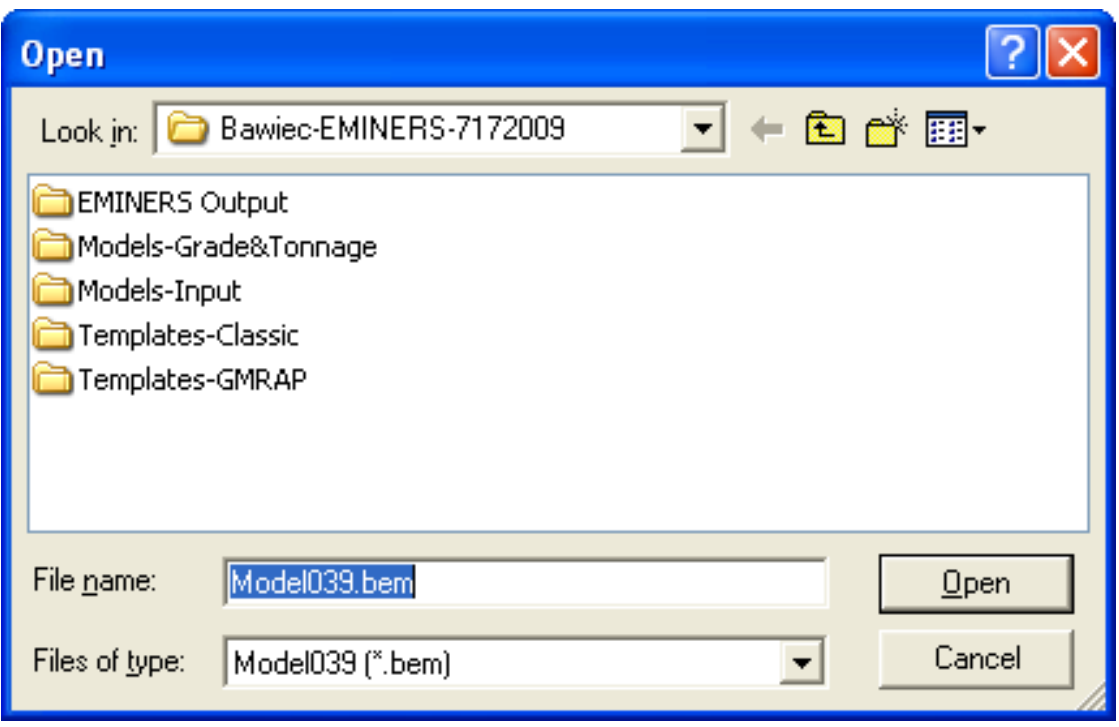

a. Double click on the Models-Input folder.

b. Click Open.

10. The window "Locate Directory for CSV files and CLICK OK." opens: 


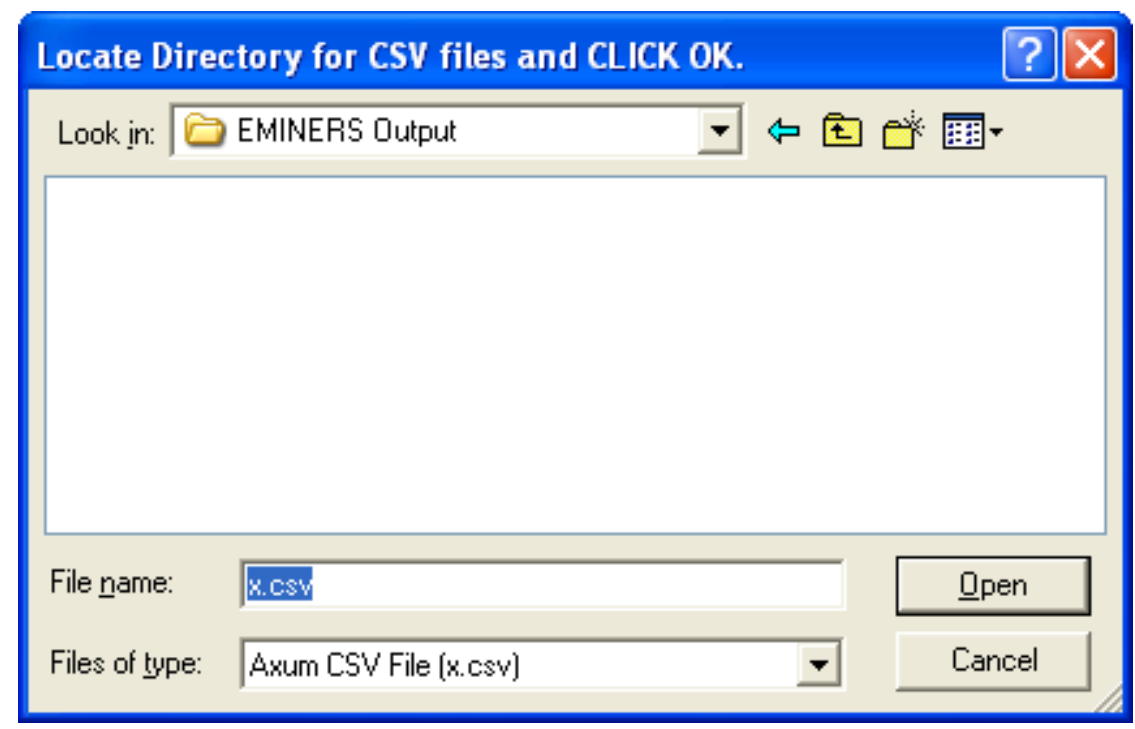

a. Navigate to the folder where the output files are to be saved; for example, the folder EMINERS Output that was created during the installation and setup. This folder can be used to store graphical output and tables.

b. Do not change the file name or file type in this box. The default file name ' $x$ ' is automatically replaced by a new name generated by the software composed of the assessment area name, a model number, and a three-digit number with the form "AAAA_Modelnnn_Excell000.csv" where AAAA is the name chosen for the assessment area, and "nnn" will be the number of the deposit model used by EMINERS (for example, 039).

c. Click OPEN (which actually means "save") to save the .csv file.

11. EMINERS executes, and the results are displayed in the window "Eminer1." 


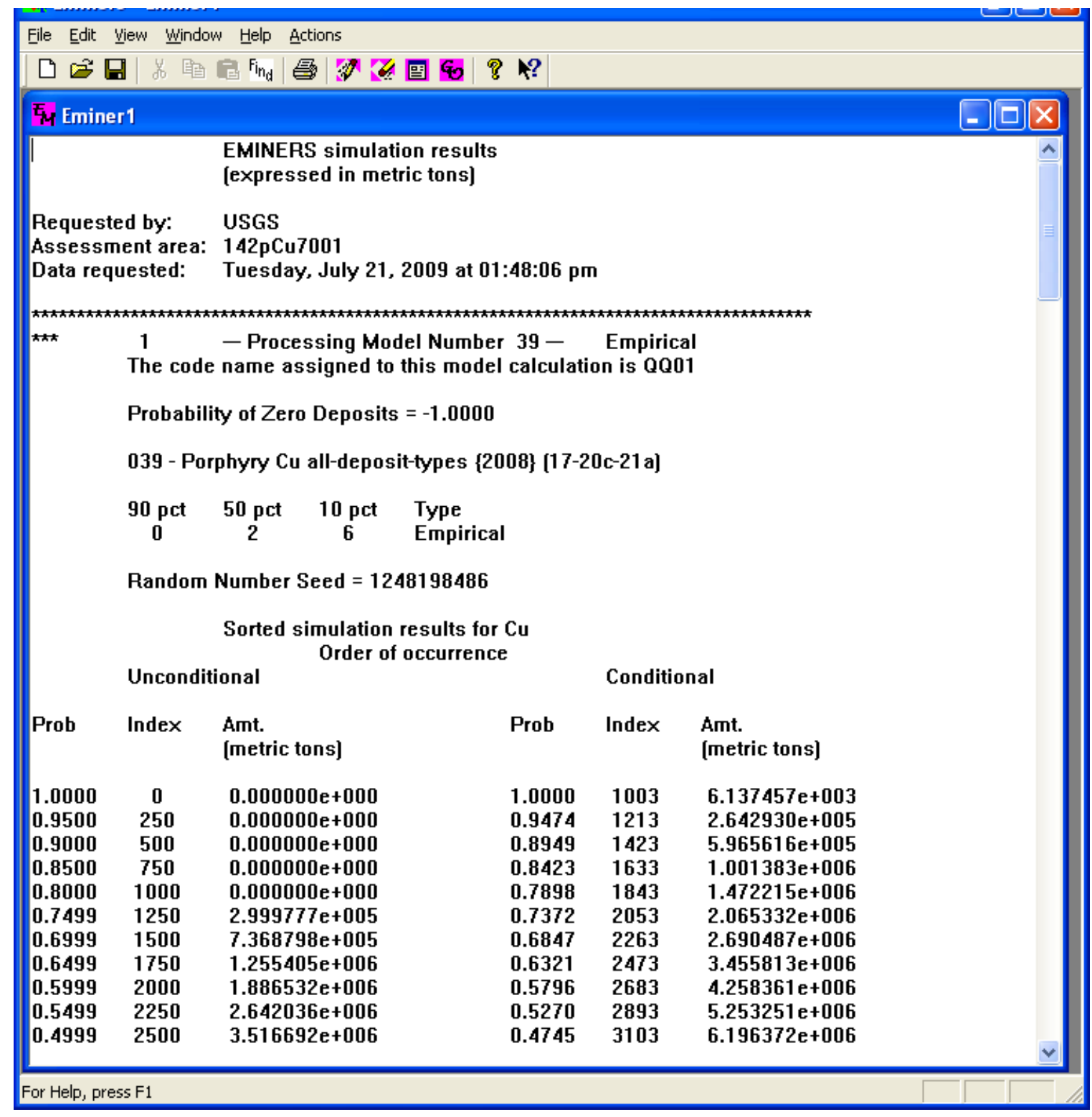

This output shows the initial data entered into EMINERS and the results of the Monte Carlo simulation, which include calculated probabilistic ranges of estimated values for commodity endowments and deposit tonnage with estimated mean values for each range, and an estimate of the mean number of undiscovered deposits. An explanation of how to read and understand this file can be found in next section of this report.

12. Under the File pull-down menu, click Save in the menu bar to open the window "Save As."

a. In the Save In: message box, browse to the EMINERS Output folder created earlier, and change the name of the file from "Eminer1.emr" to a unique name. We suggest using the assessment area tract name. The results of the simulation will be stored in a text file with the .emr extension. 


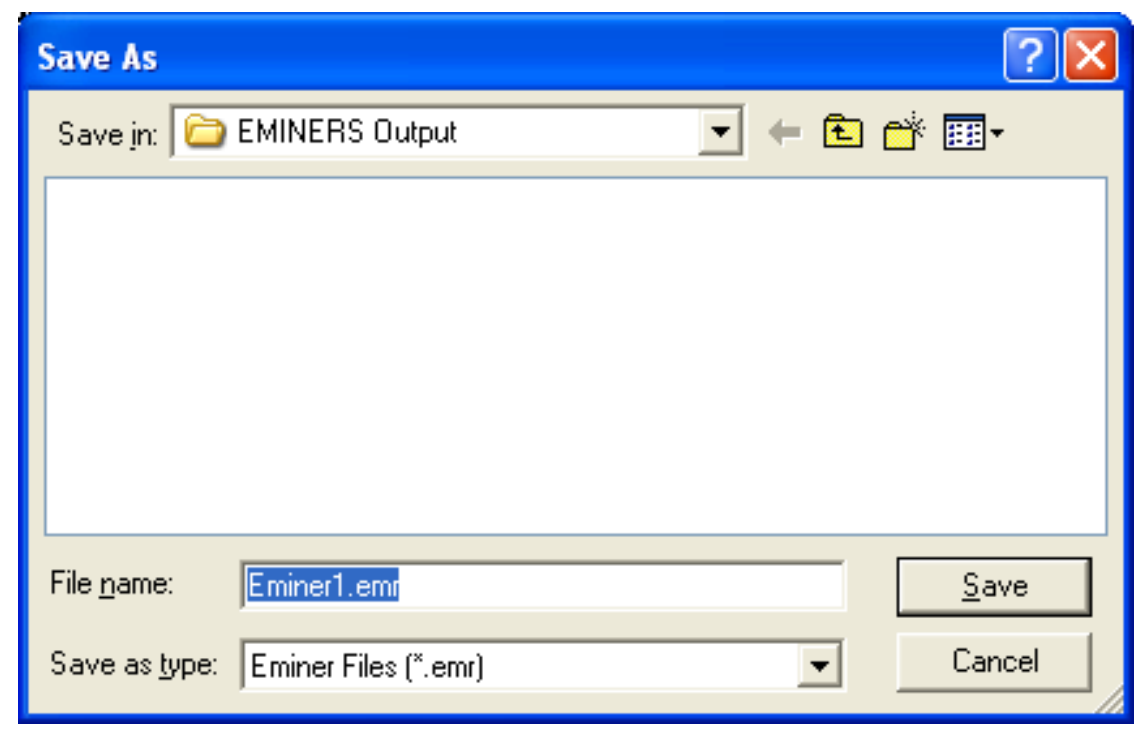

b. Click Save.

Files saved to the EMINERS Output folder include those listed in the image below:

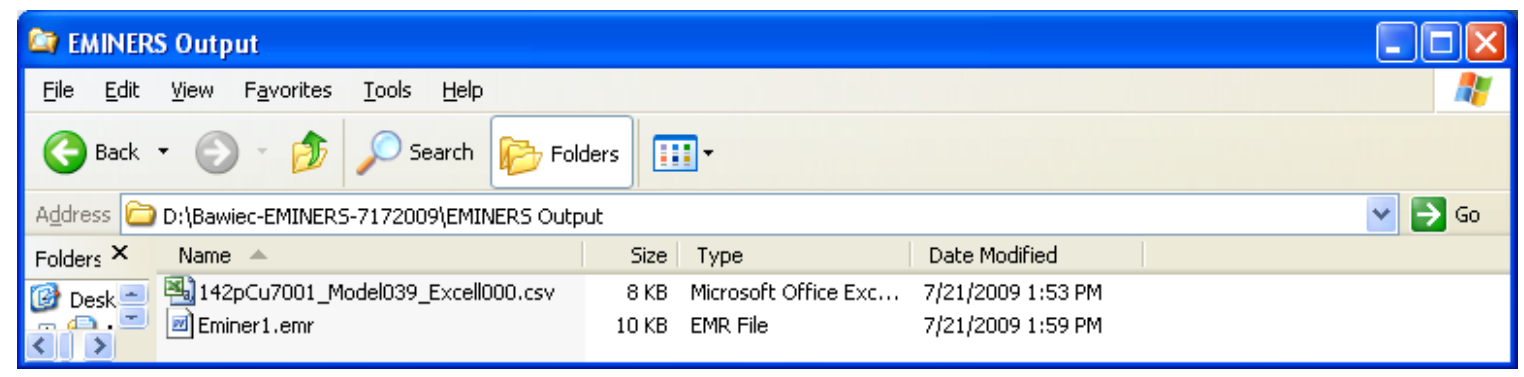

You can print the results of this window by selecting File>Print. If you have Adobe Acrobat installed, you can create a PDF file of this output by selecting Adobe PDF as your printer.

If you want to view these results again after closing the "Eminer1" window, navigate to the folder containing the .emr file saved from this simulation and use Open to open the .emr file using either Wordpad or Microsoft Word.

\section{Part II. Understanding an EMINERS Output File}

This chapter is designed to familiarize the user with the content of the EMINERS (.emr) output file. A single set of deposit estimates and a single type of deposit model are used. The resulting output report contains (1) a series of statistical summaries for each commodity and deposit tonnage included in the deposit model and (2) the expected mean number of deposits.

For illustrative purposes, only the first page of what would be a multipage output report is shown. The report contains two basic types of output, which are outlined in red in the following xample: "Input Parameters Box" and "Simulation Results Box." Each report contains a single set of input parameters, which appear in the Input Parameters Box, followed by from two to eight sets of simulation results, which appear in the Simulation Results Box. There will be one set of simulation results for each commodity, and one for deposit tonnage. An explanation of the EMINERS results can also be found in the EMINERS program Help file (Help/EMINERS Help/Discussion of the EMINERS program/Table of Contents/How to..../Interpret the Results). 
Input Parameters Box - contains a tabulation of input values that are provided by the user at the program interface at the start of a run. The numbers given below correspond to the red numerals enclosed in circles on the sample report.

1. Name of the person supplying the input data and performing the run.

2. Unique name for the assessment area.

3. Date and time stamp indicating when the EMINERS run was performed.

4. Number (1, in this example) indicates the number of models in the run, if multiple models are being run. Runs utilizing the supplied templates to create graphs and tables are limited to the use of only one model; this value will always remain 1.

5. Number (39, in this example) assigned to the deposit model in the EMINERS deposit model list (see table 1).

6. Identifies the method (empirical versus lognormal) used to approximate grade and tonnage values in the deposit models. See the EMINERS Help file for more detail on the empirical method.

7. A four-character code that is available to the user to further identify a tract being run. The default value QQ01 appears unless the user deletes or replaces the value.

8. The value for the probability of zero deposits can be equal to -1 or 0 or can be in the range of 0 to 1.0 .

9. Deposit model number (039, in this example) and model name and year (Porphyry $\mathrm{Cu}$ alldeposit-types 2008, in this example).

10. Lists the undiscovered deposit estimate set $(0,2,6$, in this example) at the $90 \%, 50 \%$, and $10 \%$ probability levels and the grade and tonnage model data approximation method (empirical or lognormal) used in a run.

11. Random number generated by the program that was used in the Monte Carlo simulation of EMINERS.

Simulation Results Box - contains summary statistical information that characterizes the 4,999member simulation population that EMINERS generates during a run. An output file contains simulation results for each commodity in a deposit model. The underlying assumption is that the randomly simulated deposits constitute a representative sample of all possible results. For each commodity, the report contains the following items:

12. Header identifying the commodity ( $\mathrm{Cu}$, in this example) to which the statistical summary applies.

13. The results of the simulation calculations are provided in the form of tables of numbers, where the amounts (Amt.) have been ordered from the smallest to the largest values. The three columns under the general heading "Unconditional" refer to the unconditional probability that includes the possibility that no deposits may exist in the area of interest. The three columns under the heading "Conditional" refer to the probability of a given amount of copper given the condition that one or more deposits actually exist.

14. The tables contain 3 columns of values, and 21 values. Total endowment simulation amounts are sorted by size from smallest to largest. The values are displayed from the smallest amounts of the distribution, and at an Index value interval of 250 (5 percentiles). Because these tables are the result of 4,999 separate simulations, the ordered data can be interpreted in terms of 
probabilities. For example, the 90th percentile is represented by a Prob $=0.9000$ and an Index of 500 ; the 50th percentile by a Prob $=0.4999$ and an Index of 2500 (with a value in this example of 3.8 million metric tons or more of copper); and the 10th percentile by a Prob $=0.0998$ with an Index of 4500 (with a value in this example of 25 million metric tons or more of copper). Values in the Unconditional table are used in the templates to construct the curves in the Cumulative Distribution Graph figure (see Part III).

15. The expected mean endowments associated with the two simulation distributions. A probability for the mean is obtained by using interpolation to determine the index value of the simulation run that falls closest in value to that of the mean.

16. Table listing the number of deposit scenarios simulated $(\mathrm{N}=)$, the number of times that each scenario was actually simulated $($ Freq $(\mathrm{N})=$ ), and the theoretical probability EMINERS assigned to each scenario $(\operatorname{Prob}(\mathrm{N})=)$. During execution, EMINERS applies a default distribution to the set of deposit estimate values provided by the assessment team to obtain theoretical probabilities for each deposit scenario ranging from 0 to a value equal to the largest value in a deposit estimate set. In the example, endowment simulations were run using 0 through 6 deposits and the default probabilities assigned were $0.2,0.2,0.15,0.1,0.1,0.1$, and 0.15 . For more detail on the assignment of default probabilities, see Root and others (1992).

17. Number of simulations run where a 0 deposit scenario was used; used to calculate probability of having no endowment. In the example, there is a 0.2 probability that there is no copper endowment present.

18. Mean number of undiscovered deposits estimated to be present in the assessment tract. 
EMINERS simulation results

(expressed in metric tons)

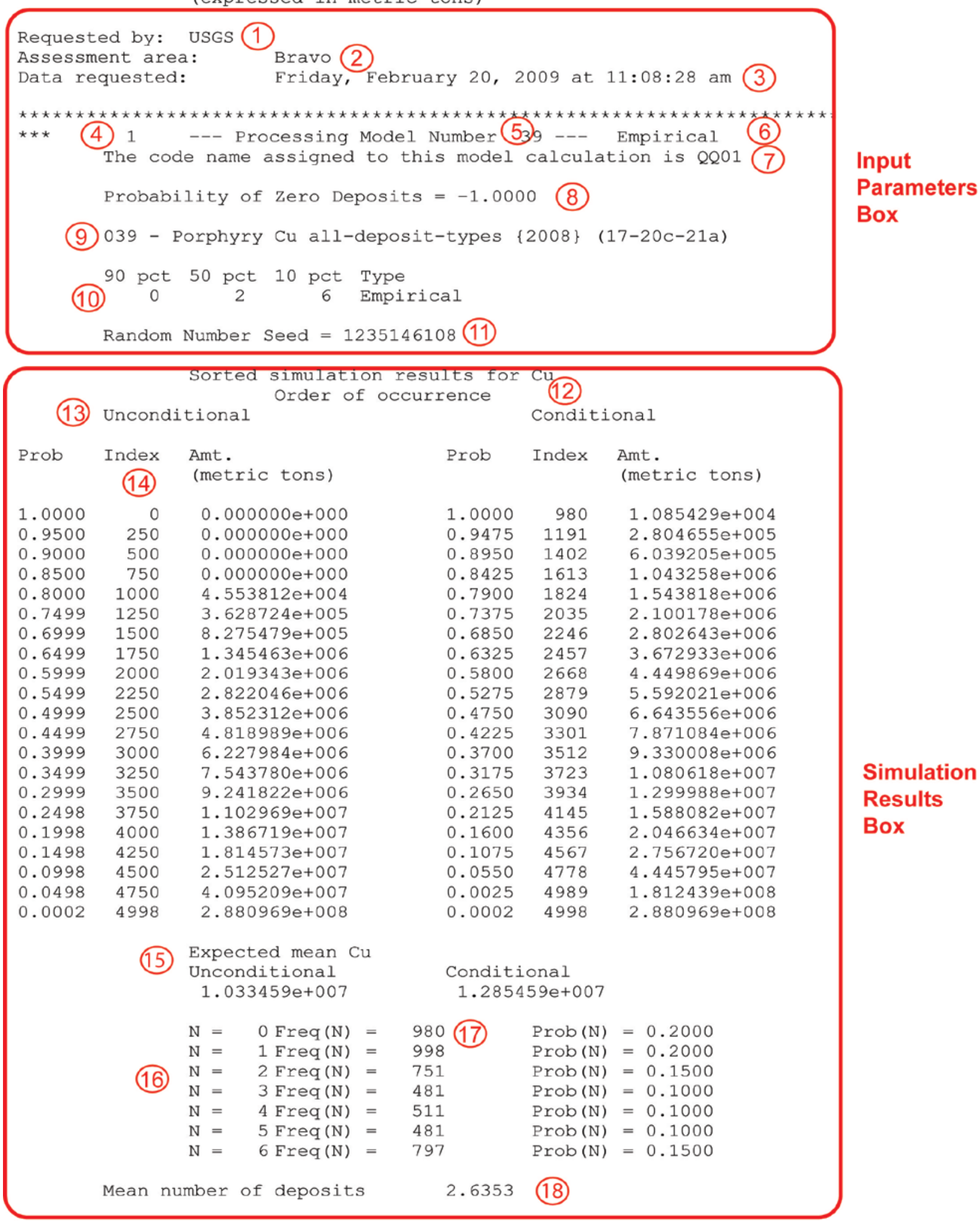




\section{Part III. Creation of Tables and Graphs by Use of Excel Templates}

As demonstrated in Part I, the output files resulting from running the EMINERS program are a text file (x.emr) and an Excel file (x.csv). Part II explains how to read the x.emr file to examine the tabular simulation results for metal and rock endowments and mean number of undiscovered deposits from EMINERS. This section demonstrates use of the Excel file (x.csv) to supply input to Microsoft Excel templates that create graphics and tables suitable for publication.

Templates are available to report results for one to seven mineral commodities. To select the correct template, the user can count the number of metals listed in the x.emr file or check table 1 for the appropriate deposit type. For example, the "Porphyry Cu (2008), all deposit types" model (model 039; see table 1) calculates metal endowments for four commodities (copper, molybdenum, gold, silver) in addition to a rock tonnage, and so the four-metal Excel template should be used.

Templates available with EMINERS version 3.0 reside in the folder named Templates. Each template produces a cumulative frequency plot, a table of statistics for estimates of undiscovered deposits, and a table of resource calculations based on the Monte Carlo simulation.

\section{Using the Templates}

1. Use Excel to open the .csv file saved from EMINERS.

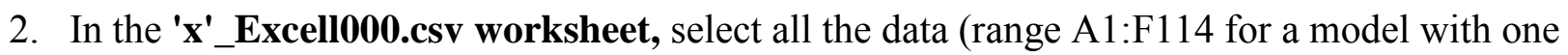
metal and A1:R114 for a model with seven metals) and use the Ctrl + C keys to copy the data to the clipboard.

3. From the Templates folder, open the appropriate Excel template, based on the number of commodities present. If a Microsoft Excel window opens and asks about updating links, click on Don't Update.

This demonstration uses the four-metal template: 


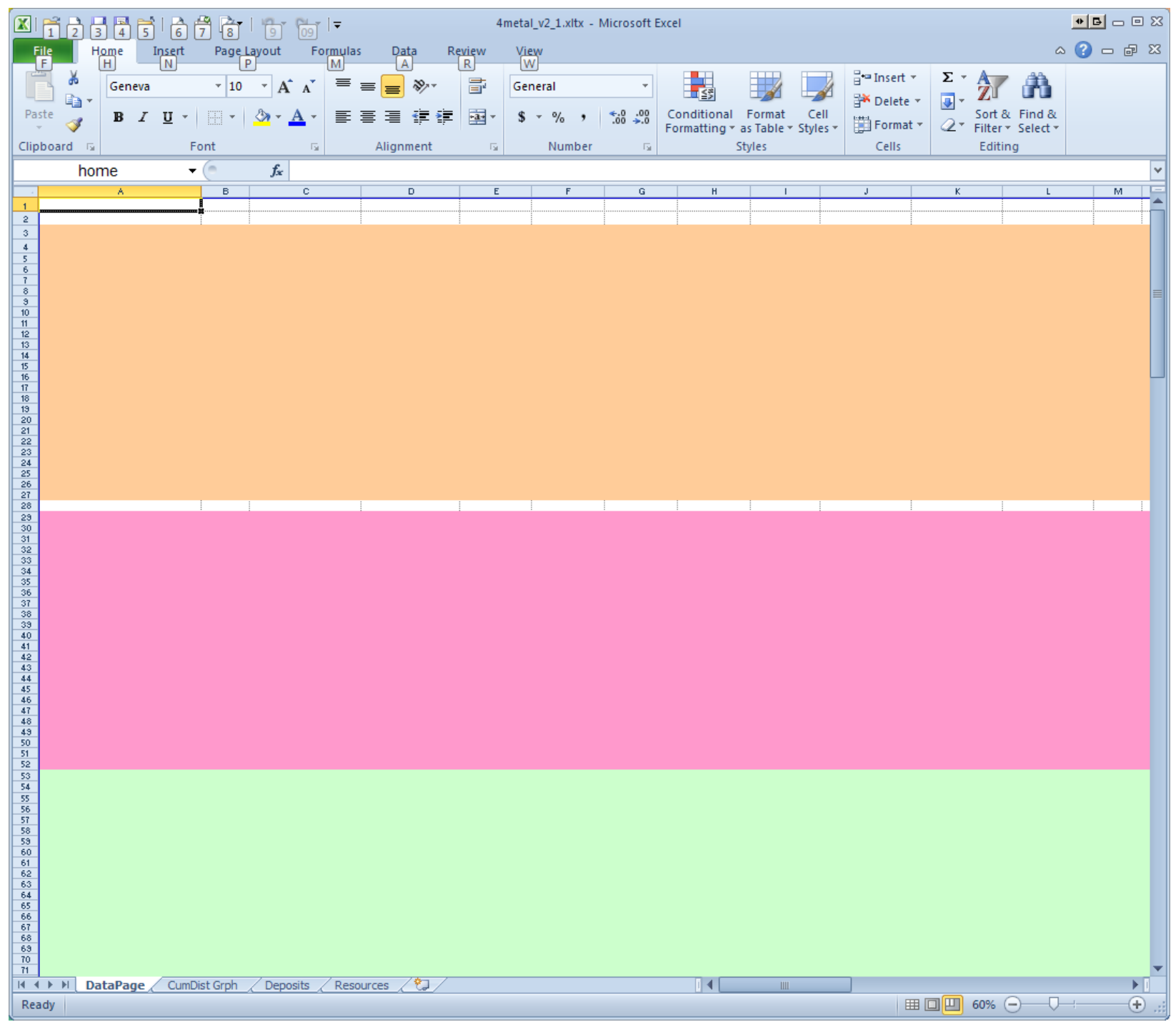

4. If the DataPage worksheet is not visible, scroll left and select it.

5. Click in cell $\mathbf{A 1}$ if it is not already selected.

6. Right click in cell A1, select Paste.

Embedded formulae in the DataPage worksheet and other worksheets will automatically fill most of the remaining data cells and create the tables and chart. Limited additional user input is required and is discussed both below and in text blocks on the individual worksheets.

\section{Graphs and Tables Available in the Templates}

1. Click on TAB CumDist Grph. 


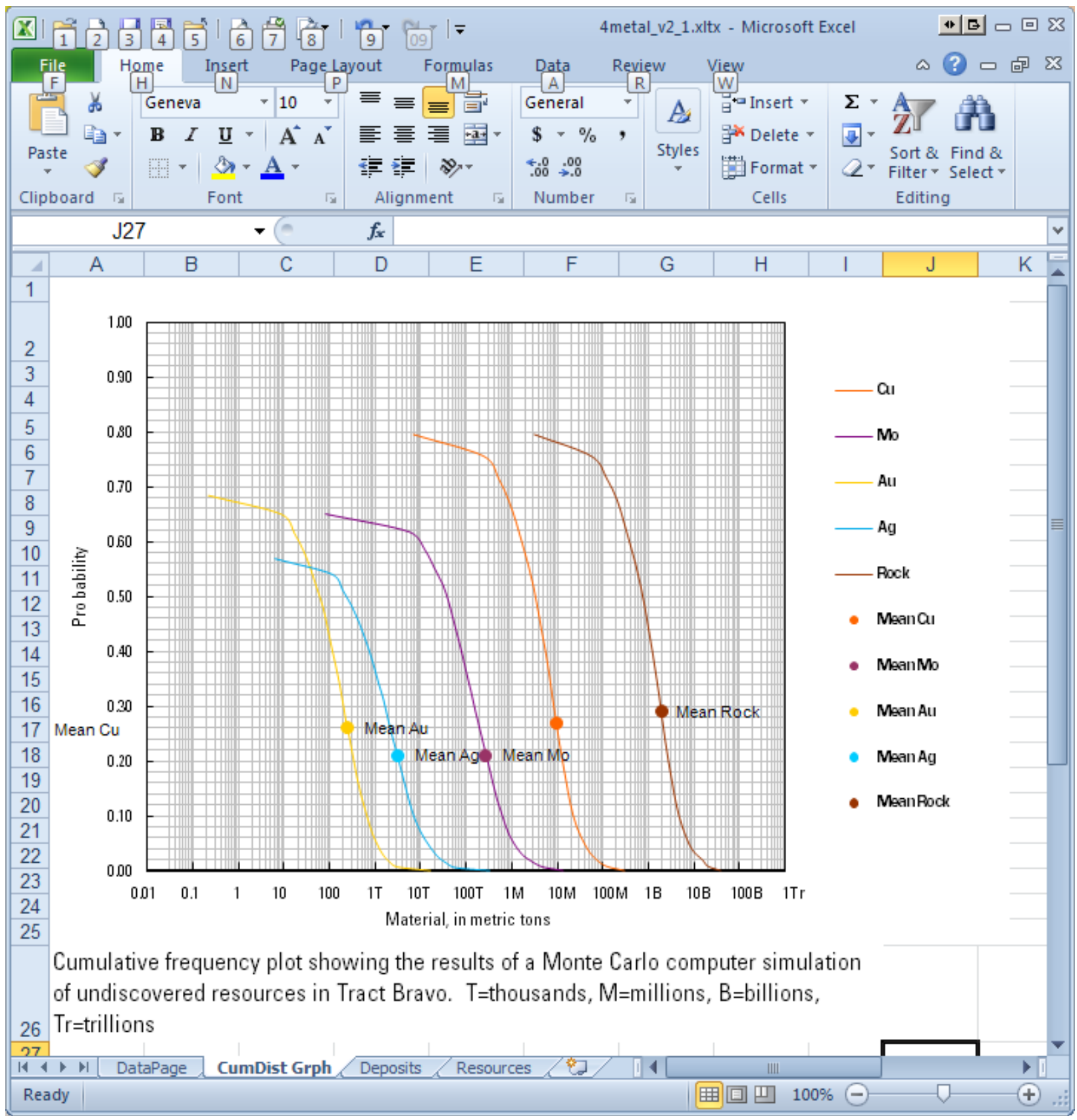

The user must confirm that all the endowment curves are fully displayed. The preset scale range for the "Material" axis will accommodate a broad range of endowment estimates. If the curves are truncated at the high or low ends of the scale range, the range must be modified. Instructions for modifying the scale range settings and the scale annotation are posted in a message box in the worksheet adjacent to the graph. The graph scale can be modified only in Excel.

A recommended procedure to use to import the graph into a Word document is also posted in the worksheet. The graph can also be exported as a .pdf file, which will require clipping.

2. Click on TAB Deposits.

Embedded formulae automatically fill most cells with values and insert the tract name in the table title. In cases where a three-tier approach is used to estimate undiscovered deposits, values are inserted automatically in the N05 and N01 cells, which are equal to the value appearing in the N10 cell. 


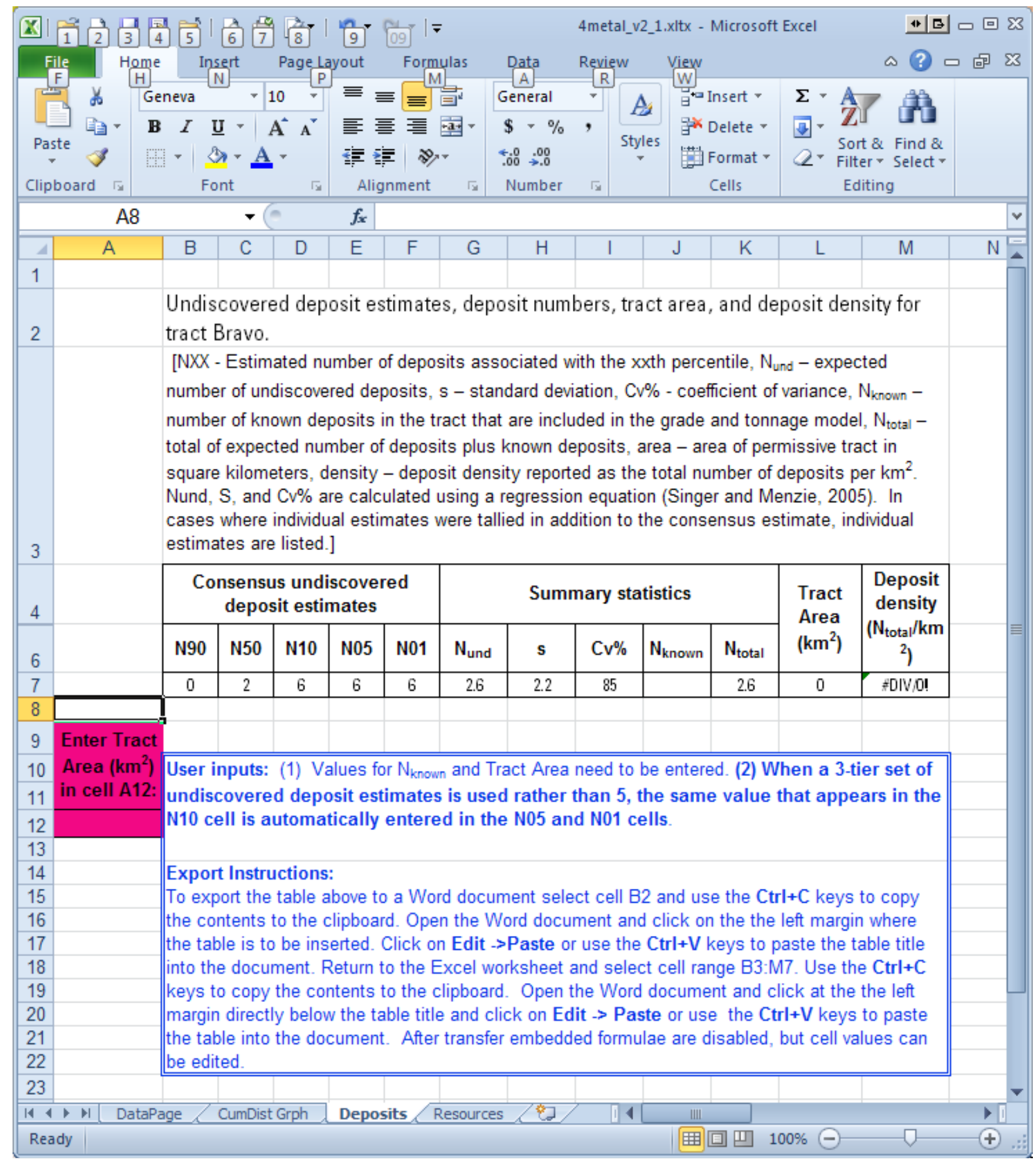

Before the table is ready for export, the user must insert values in cell $\mathrm{J} 2\left(\mathrm{~N}_{\text {known }}\right)$ and A12 (tract area, in $\mathrm{km}^{2}$ ). A recommended procedure to use to export the table to a Word document is posted in the worksheet.

As an option, a table is also provided in which the names and estimates of individual assessors can be reported. The table structure requires minor modification (addition of rows) to accommodate the names of all assessors and the consensus estimate. 


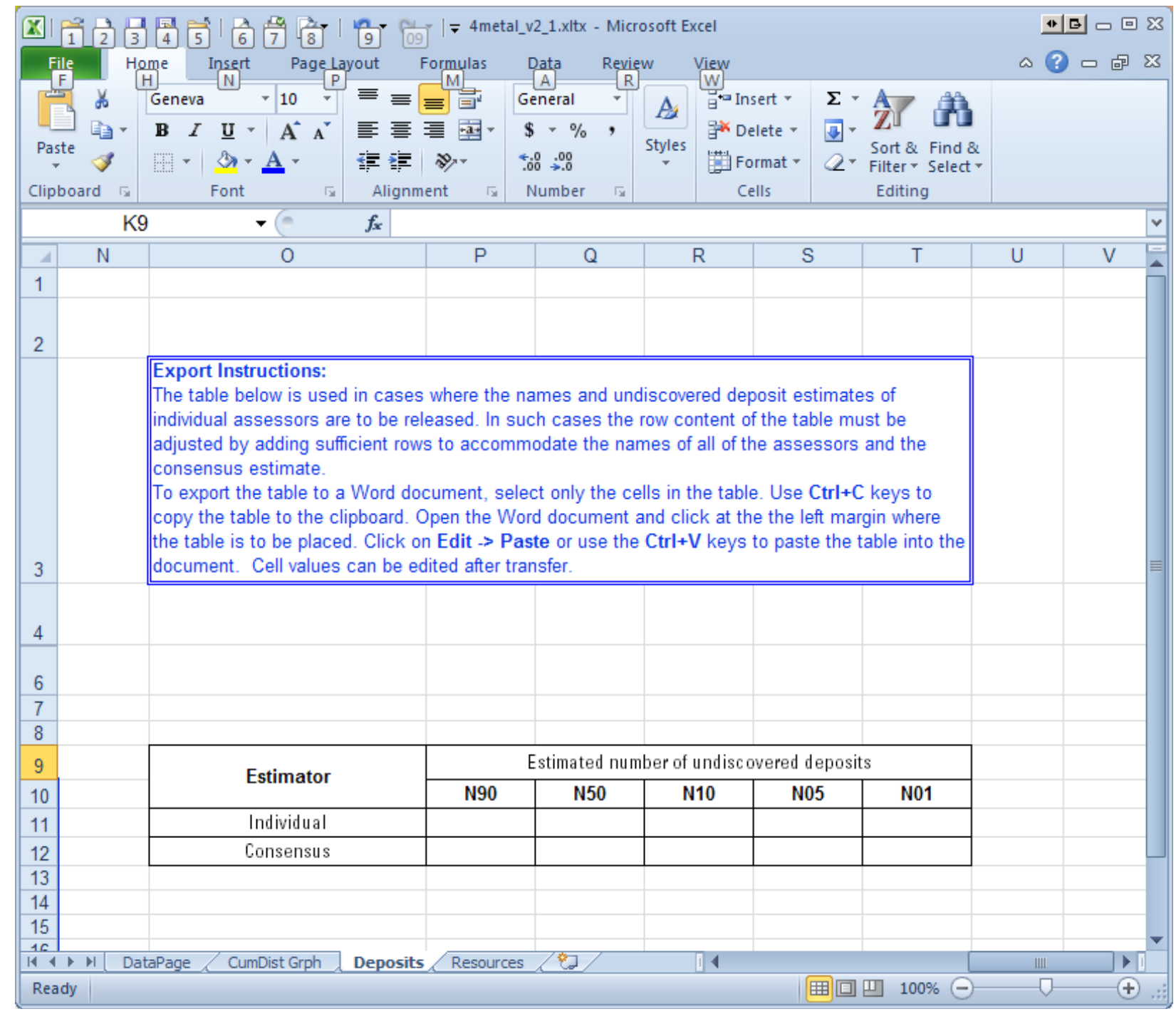

3. Click on TAB Resources. title.

Embedded formulae automatically fill all cells with values and insert the tract name in the table 


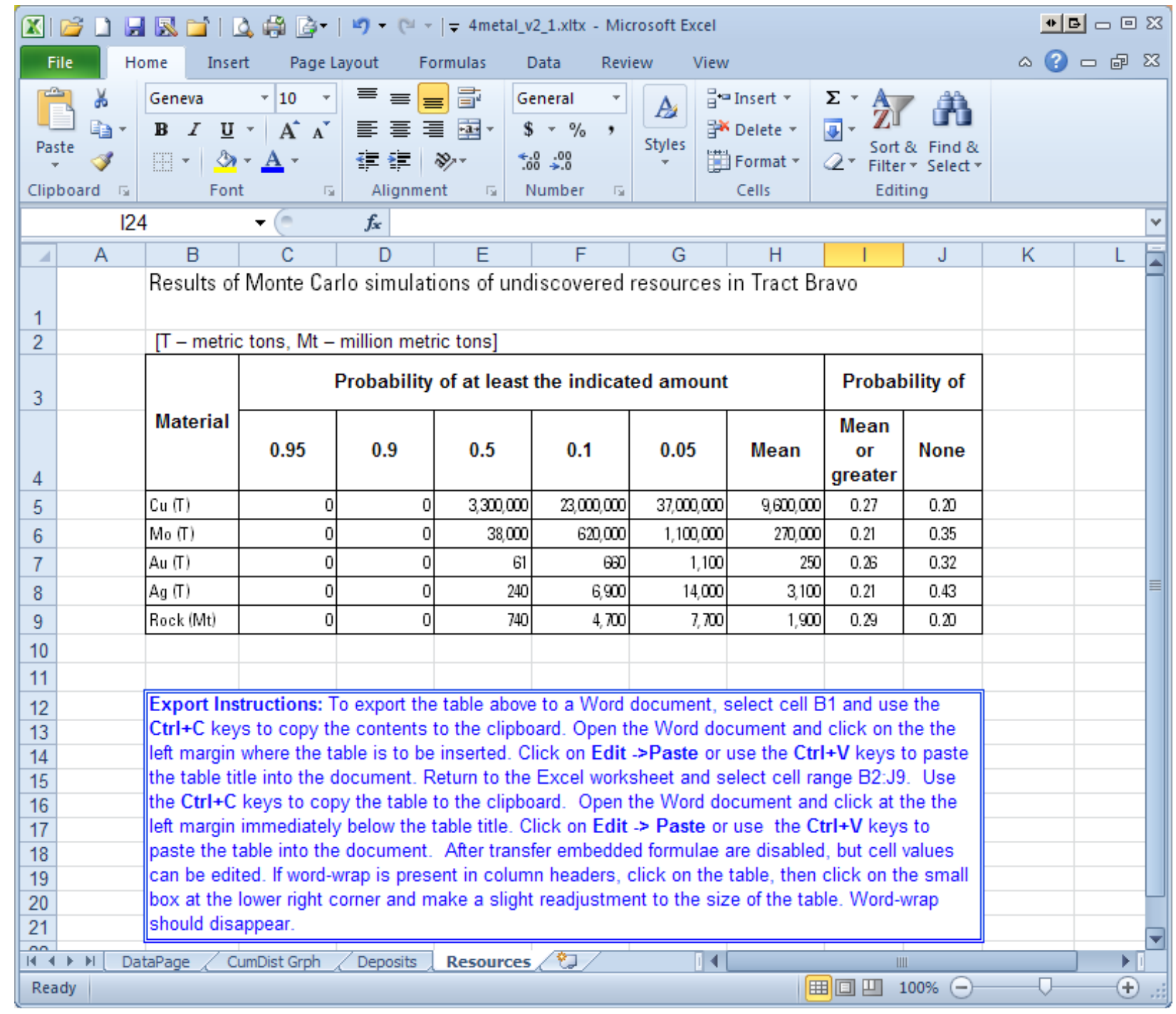

\section{Part IV. Grade and Tonnage Models}

The grade and tonnage models used in version 3.0 of EMINERS are listed in table 1.

Table 1. Listing of EMINERS model numbers, model names, commodities present, recommended template to use, and model sources.

\begin{tabular}{|l|l|l|l|l|}
\hline $\begin{array}{c}\text { EMINERS } \\
\text { model number }\end{array}$ & \multicolumn{1}{|c|}{ Model name } & Commodities present & \multicolumn{1}{c|}{ Template to use } & \multicolumn{1}{c|}{ Source } \\
\hline 1 & Amorphous graphite (1992) & Amorphous graphite & 1 metal & $\begin{array}{l}\text { Bliss and Sutphin, } \\
1992\end{array}$ \\
\hline 2 & $\begin{array}{l}\text { Au-Ag-Te veins associated } \\
\text { with alkalic rocks (1992) }\end{array}$ & $\mathrm{Au}, \mathrm{Ag}$ & 2 metal & Bliss and others, 1992 \\
\hline 3 & $\begin{array}{l}\text { Bauxite deposits, karst-type } \\
(1986)\end{array}$ & $\mathrm{Al}$ & 1 metal & Mosier, 1986b \\
\hline 4 & $\begin{array}{l}\text { Bauxite deposits, laterite-type } \\
(1986)\end{array}$ & $\mathrm{Al}$ & 1 metal & Mosier, 1986c \\
\hline 5 & Bedded barite (1992) & Barite & 1 metal & Orris, 1992a \\
\hline
\end{tabular}


Table 1. Listing of EMINERS model numbers, model names, commodities present, recommended template to use, and model sources.-Continued

\begin{tabular}{|c|c|c|c|c|}
\hline $\begin{array}{c}\text { EMINERS } \\
\text { model number }\end{array}$ & Model name & Commodities present & Template to use & Source \\
\hline 6 & Besshi massive sulfide (1986) & $\mathrm{Cu}, \mathrm{Au}, \mathrm{Ag}, \mathrm{Zn}$ & 4 metal & Singer, 1986a \\
\hline 7 & Carbonatite deposits (1998) & $\begin{array}{l}\mathrm{Nb}, \text { rare-earth oxides, } \\
\mathrm{P}\end{array}$ & 3 metal & Singer, 1998 \\
\hline 8 & Climax Mo deposits (1986) & Mo & 1 metal & $\begin{array}{l}\text { Singer, Theodore, and } \\
\text { Mosier, } 1986\end{array}$ \\
\hline 9 & $\begin{array}{l}\text { Diamond kimberlite pipes } \\
\text { (1992) }\end{array}$ & Diamond & 1 metal & Bliss, 1992d \\
\hline 10 & $\begin{array}{l}\text { Disseminated flake graphite } \\
\text { (1990) }\end{array}$ & $\begin{array}{l}\text { Disseminated flake } \\
\text { graphite }\end{array}$ & 1 metal & $\begin{array}{l}\text { Sutphin and Bliss, } \\
1990\end{array}$ \\
\hline 11 & $\begin{array}{l}\text { Distal disseminated Ag-Au } \\
\text { (1992) }\end{array}$ & $\mathrm{Au}, \mathrm{Ag}$ & 2 metal & Cox and Singer, 1992 \\
\hline 12 & Dunitic Ni-Cu (1986) & $\mathrm{Cu}, \mathrm{Ni}, \mathrm{Co}, \mathrm{Pd}, \mathrm{Ir}, \mathrm{Au}$ & 6 metal & $\begin{array}{l}\text { Singer and Page, } \\
\text { 1986a }\end{array}$ \\
\hline 13 & Epithermal Mn (1986) & $\mathrm{Mn}, \mathrm{Fe}, \mathrm{P}$ & 3 metal & Mosier, 1986a \\
\hline 14 & $\begin{array}{l}\text { Epithermal quartz-alunite } \mathrm{Au} \\
\text { (1993) }\end{array}$ & $\mathrm{Cu}, \mathrm{Au}, \mathrm{Ag}$ & 3 metal & $\begin{array}{l}\text { Singer, Mosier, and } \\
\text { Menzie, } 1993\end{array}$ \\
\hline 15 & $\begin{array}{l}\text { Epithermal veins, Comstock- } \\
\text { type (1986) }\end{array}$ & $\mathrm{Au}, \mathrm{Ag}$ & 2 metal & $\begin{array}{l}\text { Mosier, Singer, and } \\
\text { Berger, } 1986\end{array}$ \\
\hline 16 & $\begin{array}{l}\text { Epithermal veins, Creede-type } \\
\text { (1986) }\end{array}$ & $\mathrm{Au}, \mathrm{Ag}, \mathrm{Cu}, \mathrm{Pb}, \mathrm{Zn}$ & 5 metal & $\begin{array}{l}\text { Mosier, Sato, and } \\
\text { Singer, } 1986\end{array}$ \\
\hline 17 & $\begin{array}{l}\text { Epithermal veins, Sado-type } \\
\text { (1986) }\end{array}$ & $\mathrm{Cu}, \mathrm{Au}, \mathrm{Pb}, \mathrm{Ag}, \mathrm{Zn}$ & 5 metal & Mosier and Sato, 1986 \\
\hline 18 & Gold antimony deposits (1993) & $\mathrm{Sb}, \mathrm{Au}$ & 2 metal & Berger, 1993 \\
\hline 19 & Homestake Au (1993) & $\mathrm{Au}, \mathrm{Ag}$ & 2 metal & $\begin{array}{l}\text { Singer, Mosier, and } \\
\text { Menzie, } 1993\end{array}$ \\
\hline 20 & Hot-spring Au-Ag (1992) & $\mathrm{Au}, \mathrm{Ag}$ & 2 metal & $\begin{array}{l}\text { Berger and Singer, } \\
1992\end{array}$ \\
\hline 21 & Hot-spring $\mathrm{Hg}(1986)$ & $\mathrm{Hg}$ & 1 metal & Rytuba, 1986 \\
\hline 22 & Komatiitic Ni-Cu (1986) & $\begin{array}{l}\mathrm{Cu}, \mathrm{Ni}, \mathrm{Co}, \mathrm{Pd}, \mathrm{Ir}, \mathrm{Au}, \\
\mathrm{Pt}\end{array}$ & 7 metal & $\begin{array}{l}\text { Singer, Page, and } \\
\text { Menzie, 1986a }\end{array}$ \\
\hline 23 & Lacustrine borates (1992) & $\mathrm{B}$ & 1 metal & Orris, 1992d \\
\hline 24 & Laterite-saprolite $\mathrm{Au}$ (1992) & $\mathrm{Au}$ & 1 metal & Bliss, 1992b \\
\hline 25 & Lateritic Ni (1986) & $\mathrm{Ni}, \mathrm{Co}$ & 2 metal & Singer, 1986b \\
\hline 26 & $\begin{array}{l}\text { Low-sulfide Au-quartz veins } \\
\text { (1986) }\end{array}$ & $\mathrm{Au}, \mathrm{Ag}$ & 2 metal & Bliss, 1986 \\
\hline 27 & $\begin{array}{l}\text { Low-sulfide Au-quartz veins, } \\
\text { Chugach-type (1992) }\end{array}$ & $\mathrm{Au}, \mathrm{Ag}$ & 2 metal & Bliss, 1992a \\
\hline 28 & Marine bedded gypsum (1992) & Gypsum & 1 metal & Orris, 1992e \\
\hline 29 & Oolitic ironstones (1992) & $\mathrm{Fe}, \mathrm{Si}, \mathrm{P}, \mathrm{Mn}, \mathrm{Ca}, \mathrm{Al}$ & 6 metal & Orris, $1992 b$ \\
\hline 30 & $\begin{array}{l}\text { Phosphate deposits, upwelling- } \\
\text { type (1986) }\end{array}$ & $\mathrm{P}$ & 1 metal & Mosier, 1986g \\
\hline 31 & $\begin{array}{l}\text { Phosphate deposits, warm- } \\
\text { current-type (1986) }\end{array}$ & $\mathrm{P}$ & 1 metal & Mosier, 1986j \\
\hline 32 & Placer Au-PGE (1986) & $\mathrm{Au}, \mathrm{Ag}$ & 2 metal & Orris and Bliss, 1986 \\
\hline 33 & Placer PGE-Au (1986) & $\mathrm{Pt}, \mathrm{Au}, \mathrm{Os}, \mathrm{Ir}, \mathrm{Pd}$ & 5 metal & $\begin{array}{l}\text { Singer and Page, } \\
1986 \mathrm{c}\end{array}$ \\
\hline 34 & $\begin{array}{l}\text { Podiform chromite, major } \\
\text { (1986) }\end{array}$ & $\mathrm{Cr}, \mathrm{Pd}, \mathrm{Pt}, \mathrm{Ir}, \mathrm{Rh}, \mathrm{Ru}$ & 6 metal & $\begin{array}{l}\text { Singer, Page, and } \\
\text { Lipin, } 1986\end{array}$ \\
\hline
\end{tabular}


Table 1. Listing of EMINERS model numbers, model names, commodities present, recommended template to use, and model sources.-Continued

\begin{tabular}{|c|c|c|c|c|}
\hline $\begin{array}{c}\text { EMINERS } \\
\text { model number }\end{array}$ & Model name & Commodities present & Template to use & Source \\
\hline 35 & $\begin{array}{l}\text { Podiform chromite, minor } \\
\text { (1986) }\end{array}$ & $\mathrm{Cr}, \mathrm{Ir}, \mathrm{Pd}, \mathrm{Pt}, \mathrm{Rh}, \mathrm{Ru}$ & 6 metal & $\begin{array}{l}\text { Singer and Page, } \\
1986 \mathrm{~b}\end{array}$ \\
\hline 36 & $\begin{array}{l}\text { Polymetallic replacement } \\
\text { deposits (1986) }\end{array}$ & $\mathrm{Cu}, \mathrm{Au}, \mathrm{Pb}, \mathrm{Ag}, \mathrm{Zn}$ & 5 metal & $\begin{array}{l}\text { Mosier, Morris, and } \\
\text { Singer, } 1986\end{array}$ \\
\hline 37 & Polymetallic veins (1986) & $\mathrm{Cu}, \mathrm{Au}, \mathrm{Pb}, \mathrm{Ag}, \mathrm{Zn}$ & 5 metal & Bliss and Cox, 1986 \\
\hline 38 & $\begin{array}{l}\text { Porphyry } \mathrm{Cu}(2005), \text { all } \\
\text { deposit types }\end{array}$ & $\mathrm{Cu}, \mathrm{Mo}, \mathrm{Ag}, \mathrm{Au}$ & 4 metal & $\begin{array}{l}\text { Singer, Berger, and } \\
\text { Moring, } 2005\end{array}$ \\
\hline 39 & $\begin{array}{l}\text { Porphyry } \mathrm{Cu} \text { (2008), all } \\
\text { deposit types }\end{array}$ & $\mathrm{Cu}, \mathrm{Mo}, \mathrm{Ag}, \mathrm{Au}$ & 4 metal & $\begin{array}{l}\text { Singer, Berger, and } \\
\text { Moring, } 2008\end{array}$ \\
\hline 40 & $\begin{array}{l}\text { Porphyry Cu, BC-AK-subtype } \\
\text { (1993) }\end{array}$ & $\mathrm{Cu}, \mathrm{Au}, \mathrm{Mo}, \mathrm{Ag}$ & 4 metal & $\begin{array}{l}\text { Menzie and Singer, } \\
1993\end{array}$ \\
\hline 41 & $\begin{array}{l}\text { Porphyry } \mathrm{Cu}, \mathrm{Cu}-\mathrm{Au}-\text {-subtype } \\
(2005)\end{array}$ & $\mathrm{Cu}, \mathrm{Mo}, \mathrm{Ag}, \mathrm{Au}$ & 4 metal & $\begin{array}{l}\text { Singer, Berger, and } \\
\text { Moring, } 2005\end{array}$ \\
\hline 42 & $\begin{array}{l}\text { Porphyry } \mathrm{Cu}, \mathrm{Cu}-\mathrm{Au} \text {-subtype } \\
(2008)\end{array}$ & $\mathrm{Cu}, \mathrm{Mo}, \mathrm{Ag}, \mathrm{Au}$ & 4 metal & $\begin{array}{l}\text { Singer, Berger, and } \\
\text { Moring, } 2008\end{array}$ \\
\hline 43 & $\begin{array}{l}\text { Porphyry } \mathrm{Cu}, \mathrm{Cu}-\mathrm{Mo} \text {-subtype } \\
(2005)\end{array}$ & $\mathrm{Cu}, \mathrm{Mo}, \mathrm{Ag}, \mathrm{Au}$ & 4 metal & $\begin{array}{l}\text { Singer, Berger, and } \\
\text { Moring, } 2005\end{array}$ \\
\hline 44 & $\begin{array}{l}\text { Porphyry } \mathrm{Cu}, \mathrm{Cu}-\mathrm{Mo} \text {-subtype } \\
(2008)\end{array}$ & $\mathrm{Cu}, \mathrm{Mo}, \mathrm{Ag}, \mathrm{Au}$ & 4 metal & $\begin{array}{l}\text { Singer, Berger, and } \\
\text { Moring, } 2008\end{array}$ \\
\hline 45 & $\begin{array}{l}\text { Porphyry } \mathrm{Cu} \text {, giant-Andean- } \\
\text { subtype (2008) }\end{array}$ & $\mathrm{Cu}, \mathrm{Mo}, \mathrm{Ag}, \mathrm{Au}$ & 4 metal & $\begin{array}{l}\text { Singer, Briskey, and } \\
\text { Cunningham, } 2008\end{array}$ \\
\hline 46 & $\begin{array}{l}\text { Porphyry Mo, low-F-subtype } \\
\text { (1986) }\end{array}$ & Mo & 1 metal & $\begin{array}{l}\text { Menzie and Theodore, } \\
1986\end{array}$ \\
\hline 47 & $\begin{array}{l}\text { Potash-bearing bedded salt } \\
(2008)\end{array}$ & Potash & 1 metal & $\begin{array}{l}\text { Greta Orris, written } \\
\text { commun. }\end{array}$ \\
\hline 48 & Replacement Mn (1986) & $\mathrm{Mn}, \mathrm{Fe}, \mathrm{P}, \mathrm{Cu}$ & 4 metal & Mosier, 1986d \\
\hline 49 & Replacement Sn (1986) & $\mathrm{Sn}$ & 1 metal & $\begin{array}{l}\text { Menzie and Reed, } \\
\text { 1986a }\end{array}$ \\
\hline 50 & Rhyolite-hosted Sn (1986) & $\mathrm{Sn}$ & 1 metal & $\begin{array}{l}\text { Singer and Mosier, } \\
1986 \mathrm{c}\end{array}$ \\
\hline 51 & $\begin{array}{l}\text { Sandstone-hosted Pb-Zn } \\
(1986)\end{array}$ & $\mathrm{Cu}, \mathrm{Au}, \mathrm{Pb}, \mathrm{Ag}, \mathrm{Zn}$ & 5 metal & Mosier, 1986e \\
\hline 52 & $\begin{array}{l}\text { Sedimentary exhalative } \mathrm{Zn}-\mathrm{Pb} \\
\text { (1993) }\end{array}$ & $\mathrm{Ag}, \mathrm{Cu}, \mathrm{Pb}, \mathrm{Zn}$ & 4 metal & $\begin{array}{l}\text { Singer, Mosier, and } \\
\text { Menzie, } 1993\end{array}$ \\
\hline 53 & Sedimentary Mn (1986) & $\mathrm{Mn}$ & 1 metal & $\begin{array}{l}\text { Singer, Mosier, and } \\
\text { Menzie, } 1993\end{array}$ \\
\hline 54 & Sediment-hosted Au (1992) & $\mathrm{Au}, \mathrm{Ag}$ & 2 metal & $\begin{array}{l}\text { Mosier and others, } \\
1992\end{array}$ \\
\hline 55 & Sediment-hosted $\mathrm{Cu}$ (2003) & $\mathrm{Cu}, \mathrm{Co}, \mathrm{Ag}$ & 3 metal & $\begin{array}{l}\text { Cox and others, } 2003 \\
\text { (revised 2007) }\end{array}$ \\
\hline 56 & $\begin{array}{l}\text { Sediment-hosted } \mathrm{Cu} \text {, redbed- } \\
\text { subtype (2003) }\end{array}$ & $\mathrm{Cu}, \mathrm{Co}, \mathrm{Ag}$ & 3 metal & $\begin{array}{l}\text { Cox and others, } 2003 \\
\text { (revised 2007) }\end{array}$ \\
\hline 57 & $\begin{array}{l}\text { Sediment-hosted } \mathrm{Cu} \text {, reduced } \\
\text { facies-subtype }(2003)\end{array}$ & $\mathrm{Cu}, \mathrm{Co}, \mathrm{Ag}$ & 3 metal & $\begin{array}{l}\text { Cox and others, } 2003 \\
\text { (revised 2007) }\end{array}$ \\
\hline 58 & $\begin{array}{l}\text { Sediment-hosted } \mathrm{Cu}, \text { Revett- } \\
\text { subtype (2003) }\end{array}$ & $\mathrm{Cu}, \mathrm{Ag}$ & 2 metal & $\begin{array}{l}\text { Cox and others, } 2003 \\
\text { (revised 2007) }\end{array}$ \\
\hline 59 & $\begin{array}{l}\text { Serpentine-hosted asbestos } \\
\text { (1993) }\end{array}$ & Asbestos & 1 metal & Orris, 1992c \\
\hline
\end{tabular}


Table 1. Listing of EMINERS model numbers, model names, commodities present, recommended template to use, and model sources.-Continued

\begin{tabular}{|c|c|c|c|c|}
\hline $\begin{array}{c}\text { EMINERS } \\
\text { model number }\end{array}$ & Model name & Commodities present & Template to use & Source \\
\hline 60 & Shoreline placer Ti (1986) & $\begin{array}{l}\text { Rutile, ilmenite, } \\
\text { leucoxene, zircon, } \\
\text { monazite }\end{array}$ & 5 metal & $\begin{array}{l}\text { Attanasi and } \\
\text { DeYoung, } 1986\end{array}$ \\
\hline 61 & Silica-carbonate Hg (1986) & $\mathrm{Hg}$ & 1 metal & $\begin{array}{l}\text { Rytuba and Cargill, } \\
1986\end{array}$ \\
\hline 62 & Simple Sb deposits (1986) & $\mathrm{Sb}$ & 1 metal & Bliss and Orris, 1986 \\
\hline 63 & Skarn Cu (1986) & $\mathrm{Cu}, \mathrm{Au}, \mathrm{Ag}$ & 3 metal & $\begin{array}{l}\text { Jones and Menzie, } \\
1986\end{array}$ \\
\hline 64 & Skarn Fe (1986) & $\mathrm{Fe}$ & 1 metal & $\begin{array}{l}\text { Mosier and Menzie, } \\
1986\end{array}$ \\
\hline 65 & Skarn Sn (1986) & $\mathrm{Sn}$ & 1 metal & $\begin{array}{l}\text { Menzie and Reed, } \\
\text { 1986c }\end{array}$ \\
\hline 66 & Skarn W (1992) & $\mathrm{W}$ & 1 metal & $\begin{array}{l}\text { Menzie, Jones, and } \\
\text { Elliott, } 1992\end{array}$ \\
\hline 67 & Skarn Zn-Pb (1986) & $\mathrm{Cu}, \mathrm{Au}, \mathrm{Pb}, \mathrm{Ag}, \mathrm{Zn}$ & 5 metal & Mosier, 1986k \\
\hline 68 & Sn greisen deposits (1986) & $\mathrm{Sn}$ & 1 metal & $\begin{array}{l}\text { Menzie and Reed, } \\
1986 \mathrm{~b}\end{array}$ \\
\hline 69 & Sn veins (1986) & Sn & 1 metal & $\begin{array}{l}\text { Menzie and Reed, } \\
\text { 1986d }\end{array}$ \\
\hline 70 & $\begin{array}{l}\text { Solution-collapse breccia pipe } \\
\text { uranium deposits (1992) }\end{array}$ & $\mathrm{U}$ & 1 metal & $\begin{array}{l}\text { Finch, Pierson, and } \\
\text { Sutphin, } 1992\end{array}$ \\
\hline 71 & $\begin{array}{l}\text { Southeast Missouri Pb-Zn and } \\
\text { Appalachian } \mathrm{Zn}(1986)\end{array}$ & $\mathrm{Zn}, \mathrm{Pb}, \mathrm{Ag}$ & 3 metal & $\begin{array}{l}\text { Mosier and Briskey, } \\
1986\end{array}$ \\
\hline 72 & $\begin{array}{l}\text { Superior Fe and Algoma Fe } \\
\text { deposits (1986) }\end{array}$ & $\mathrm{Fe}, \mathrm{P}$ & 2 metal & $\begin{array}{l}\text { Mosier and Singer, } \\
1986\end{array}$ \\
\hline 73 & $\begin{array}{l}\text { Synorogenic-synvolcanic Ni- } \\
\mathrm{Cu}(1986)\end{array}$ & $\mathrm{Cu}, \mathrm{Ni}, \mathrm{Co}, \mathrm{Pd}, \mathrm{Au}, \mathrm{Pt}$ & 6 metal & $\begin{array}{l}\text { Singer, Page, and } \\
\text { Menzie, 1986b }\end{array}$ \\
\hline 74 & $\begin{array}{l}\text { Thorium-rare-earth veins } \\
\text { (1986) }\end{array}$ & Th, REO & 2 metal & Bliss, 1992c \\
\hline 75 & Unconformity U-Au (1986) & $\mathrm{U}$ & 1 metal & Mosier, 1986f \\
\hline 76 & $\begin{array}{l}\text { Volcanic-hosted magnetite } \\
\text { (1986) }\end{array}$ & $\mathrm{Fe}, \mathrm{P}$ & 2 metal & Mosier, 1986h \\
\hline 77 & $\begin{array}{l}\text { Volcanogenic massive sulfide, } \\
\text { Cyprus-type (1986) }\end{array}$ & $\mathrm{Cu}, \mathrm{Au}, \mathrm{Pb}, \mathrm{Ag}, \mathrm{Zn}$ & 5 metal & $\begin{array}{l}\text { Singer and Mosier, } \\
1986 \mathrm{a}\end{array}$ \\
\hline 78 & $\begin{array}{l}\text { Volcanogenic massive sulfide, } \\
\text { kuroko-type (1986) }\end{array}$ & $\mathrm{Cu}, \mathrm{Au}, \mathrm{Pb}, \mathrm{Ag}, \mathrm{Zn}$ & 5 metal & $\begin{array}{l}\text { Singer and Mosier, } \\
1986 b\end{array}$ \\
\hline 79 & $\begin{array}{l}\text { Volcanogenic massive sulfide, } \\
\text { Sierran-kuroko-type (1992) }\end{array}$ & $\mathrm{Cu}, \mathrm{Au}, \mathrm{Pb}, \mathrm{Ag}, \mathrm{Zn}$ & 5 metal & Singer, 1992 \\
\hline 80 & $\begin{array}{l}\text { Volcanogenic Mn, Cuban-type } \\
\text { (1993) }\end{array}$ & $\mathrm{Mn}$ & 1 metal & $\begin{array}{l}\text { Singer, Mosier, and } \\
\text { Menzie, } 1993\end{array}$ \\
\hline 81 & $\begin{array}{l}\text { Volcanogenic Mn, Cyprus- } \\
\text { type (1988) }\end{array}$ & $\mathrm{Mn}, \mathrm{Fe}$ & 2 metal & $\begin{array}{l}\text { Mosier and Page, } \\
1988\end{array}$ \\
\hline 82 & $\begin{array}{l}\text { Volcanogenic Mn, Franciscan- } \\
\text { type (1993) }\end{array}$ & $\mathrm{Mn}$ & 1 metal & $\begin{array}{l}\text { Singer, Mosier, and } \\
\text { Menzie, } 1993\end{array}$ \\
\hline 83 & $\begin{array}{l}\text { Volcanogenic Mn, Olympic } \\
\text { Peninsula-type (1988) }\end{array}$ & $\mathrm{Mn}$ & 1 metal & $\begin{array}{l}\text { Mosier and Page, } \\
1988\end{array}$ \\
\hline 84 & Volcanogenic U (1986) & Mo, U & 2 metal & Mosier, 1986i \\
\hline
\end{tabular}


Table 1. Listing of EMINERS model numbers, model names, commodities present, recommended template to use, and model sources.-Continued

\begin{tabular}{|l|l|l|l|l|}
\hline $\begin{array}{c}\text { EMINERS } \\
\text { model number }\end{array}$ & \multicolumn{1}{|c|}{ Model name } & Commodities present & \multicolumn{1}{|c|}{ Template to use } & \multicolumn{1}{c|}{ Source } \\
\hline 85 & $\begin{array}{l}\text { Wolframite-bearing quartz } \\
\text { vein deposits (1992) }\end{array}$ & W & 1 metal & $\begin{array}{l}\text { Menzie, Jones, and } \\
\text { Elliott, 1992 }\end{array}$ \\
\hline 86 & Diapiric potash (2009) & Potash & 1 metal & $\begin{array}{l}\text { G. Orris (written } \\
\text { commun., 2009) }\end{array}$ \\
\hline 87 & $\begin{array}{l}\text { Diapiric potash Canadian sub- } \\
\text { type }\end{array}$ & Potash & 1 metal & $\begin{array}{l}\text { G. Orris (written } \\
\text { commun., 2009) }\end{array}$ \\
\hline
\end{tabular}

\section{References Cited}

The list below includes references cited in this report and sources for models listed in table 1.

Many models are from U.S. Geological Survey Bulletins 1693 and 2004, which are available online at the addresses below, which are not repeated for each model citation:

http://pubs.usgs.gov/bul/b1693/

http://pubs.usgs.gov/bul/b2004/

Attanasi, E.D., and DeYoung, J.H., Jr., 1986, Grade and tonnage model of shoreline placer Ti, in Cox, D.P., and Singer, D.A., eds., Mineral deposit models: U.S. Geological Survey Bulletin 1693, p. 270273.

Berger, B.R., and Singer, D.A., 1992, Grade and tonnage model of hot spring Au-Ag, in Bliss, J.D., ed., Developments in mineral deposit modeling: U.S. Geological Survey Bulletin 2004, p. 23-25.

Berger, V.I., 1993, Descriptive, and grade and tonnage model for gold-antimony deposits: U.S.

Geological Survey Open-File Report 93-0194, 24 p.

Bliss, J.D., 1986, Grade and tonnage model of low-sulfide Au-quartz veins, in Cox, D.P., and Singer, D.A., eds., Mineral deposit models: U.S. Geological Survey Bulletin 1693, p. 239-243.

Bliss, J.D., 1992a, Grade and tonnage model of Chugach-type low-sulfide Au-quartz veins, in Bliss, J.D., ed., Developments in mineral deposit modeling: U.S. Geological Survey Bulletin 2004, p. 4446.

Bliss, J.D., 1992b, Grade and tonnage model of laterite-saprolite Au, in Bliss, J.D., ed., Developments in mineral deposit modeling: U.S. Geological Survey Bulletin 2004, p. 50-51.

Bliss, J.D., 1992c, Grade and tonnage model of thorium-rare-earth veins, in Bliss, J.D., ed.,

Developments in mineral deposit modeling: U.S. Geological Survey Bulletin 2004, p. 16-18.

Bliss, J.D., 1992d, Grade-tonnage and other models for diamond kimberlite pipes: Nonrenewable Resources, v. 1, no. 3, p. 214-230.

Bliss, J.D., and Cox, D.P., 1986, Grade and tonnage model of polymetallic veins, in Cox, D.P., and Singer, D.A., eds., Mineral deposit models: U.S. Geological Survey Bulletin 1693, p. 125-129.

Bliss, J.D., and Orris, G.J., 1986, Grade and tonnage model of simple Sb deposits, in Cox, D.P., and Singer, D.A., eds., Mineral deposit models: U.S. Geological Survey Bulletin 1693, p. 184-186.

Bliss, J.D., and Sutphin, D.M., 1992, Grade and tonnage model of amorphous graphite, in Orris, G.J., and Bliss, J.D., eds., Industrial minerals deposit models - Grade and tonnage models: U.S. Geological Survey Open-File Report 92-437, p. 23-25.

Bliss, J.D., Sutphin, D.M., Mosier, D.L., and Allen, M.S., 1992, Grade-tonnage and target-area models of Au-Ag-Te veins associated with alkalic rocks: U.S. Geological Survey Open-File Report 92-208, $15 \mathrm{p}$. 
Camm, T.W., 1991, Simplified cost models for prefeasibility mineral evaluations: U.S. Bureau of Mines Information Circular 9298, 35 p. (Also available at http://pubs.usgs.gov/usbmic/ic9298/html/cammfrms.htm.)

Cox, D.P., Lindsey, D.A., Singer, D.A., Moring, Barry, and Diggles, M.F., 2003 [revised 2007], Sediment-hosted copper deposits of the world-Deposit models and database: U.S. Geological Survey Open-File Report 2003-107 version 1.3, 50 p., available at http://pubs.usgs.gov/of/2003/of03-107/.

Cox, D.P., and Singer, D.A., 1992, Grade and tonnage model of distal disseminated Ag-Au, in Bliss, J.D., ed., Developments in mineral deposit modeling: U.S. Geological Survey Bulletin 2004, p. $20-22$.

Duval, J.S., 2000, A Microsoft Windows version of the MARK3 Monte Carlo mineral resource simulator: U.S. Geological Survey Open-File Report 00-415, 1 CD-ROM. (Also available at http://pubs.usgs.gov/of/2000/of00-415/.)

Duval, J.S., 2012, Version 3.0 of EMINERS—Economic Mineral Resource Simulator: U.S. Geological Survey Open-File Report 2004-1344, available only at http://pubs.usgs.gov/of/2004/1344. (Version 3.0 of EMINERS updates version 2.0, released in 2004 as USGS OFR 2004-1344. Version 2.0 of EMINERS superseded USGS OFR 2002-0380.)

Finch, W.I., Pierson, C.T., and Sutphin, H.B., 1992, Grade and tonnage model of solution-collapse breccia pipe uranium deposits, in Bliss, J.D., ed., Developments in mineral deposit modeling: U.S. Geological Survey Bulletin 2004, p. 36-38.

Jones, G.M., and Menzie, W.D., 1986, Grade and tonnage model of Cu skarn deposits, in Cox, D.P., and Singer, D.A., eds., Mineral deposit models: U.S. Geological Survey Bulletin 1693, p. 86-89.

Menzie, W.D., Jones, G.M., and Elliott, J.E., 1992, Tungsten-Grades and tonnages of some deposits, in DeYoung, J.H., Jr., and Hammarstrom, J.M., eds., Contributions to commodity geology research: U.S. Geological Survey Bulletin 1877, p. J1-J7.

Menzie, W.D., and Reed, B.L., 1986a, Grade and tonnage model of replacement Sn, in Cox, D.P., and Singer, D.A., eds., Mineral deposit models: U.S. Geological Survey Bulletin 1693, p. 62-63.

Menzie, W.D., and Reed, B.L., 1986b, Grade and tonnage model of Sn greisen deposits, in Cox, D.P., and Singer, D.A., eds., Mineral deposit models: U.S. Geological Survey Bulletin 1693, p. 71-72.

Menzie, W.D., and Reed, B.L., 1986c, Grade and tonnage model of Sn skarn, in Cox, D.P., and Singer, D.A., eds., Mineral deposit models: U.S. Geological Survey Bulletin 1693, p. 58-60.

Menzie, W.D., and Reed, B.L., 1986d, Grade and tonnage model of Sn veins, in Cox, D.P., and Singer, D.A., eds., Mineral deposit models: U.S. Geological Survey Bulletin 1693, p. 67-69.

Menzie, W.D., and Singer, D.A., 1993, Grade and tonnage model of porphyry Cu deposits in British Columbia, Canada, and Alaska, U.S.A.: U.S. Geological Survey Open-File Report 93-0275, 9 p. (Also available at http://pubs.usgs.gov/of/1993/ofr-93-0275/.)

Menzie, W.D., and Theodore, T.G., 1986, Grade and tonnage model of porphyry Mo, low-F, in Cox, D.P., and Singer, D.A., eds., Mineral deposit models: U.S. Geological Survey Bulletin 1693, p. 120122.

Mosier, D.L., 1986a, Grade and tonnage model of epithermal Mn, in Cox, D.P., and Singer, D.A., eds., Mineral deposit models: U.S. Geological Survey Bulletin 1693, p. 166-167.

Mosier, D.L., 1986b, Grade and tonnage model of karst type bauxite deposits, in Cox, D.P., and Singer, D.A., eds., Mineral deposit models: U.S. Geological Survey Bulletin 1693, p. 258-260.

Mosier, D.L., 1986c, Grade and tonnage model of laterite type bauxite deposits, in Cox, D.P., and Singer, D.A., eds., Mineral deposit models: U.S. Geological Survey Bulletin 1693, p. 255-257.

Mosier, D.L., 1986d, Grade and tonnage model of replacement Mn, in Cox, D.P., and Singer, D.A., eds., Mineral deposit models: U.S. Geological Survey Bulletin 1693, p. 105-107. 
Mosier, D.L., 1986e, Grade and tonnage model of sandstone-hosted Pb-Zn, in Cox, D.P., and Singer, D.A., eds., Mineral deposit models: U.S. Geological Survey Bulletin 1693, p. 202-204.

Mosier, D.L., 1986f, Grade and tonnage model of unconformity U-Au, in Cox, D.P., and Singer, D.A., eds., Mineral deposit models: U.S. Geological Survey Bulletin 1693, p. 249-250.

Mosier, D.L., 1986g, Grade and tonnage model of upwelling type phosphate deposits, in Cox, D.P., and Singer, D.A., eds., Mineral deposit models: U.S. Geological Survey Bulletin 1693, p. 234-236.

Mosier, D.L., 1986h, Grade and tonnage model of volcanic-hosted magnetite, in Cox, D.P., and Singer, D.A., eds., Mineral deposit models: U.S. Geological Survey Bulletin 1693, p. 172-174.

Mosier, D.L., 1986i, Grade and tonnage model of volcanogenic U, in Cox, D.P., and Singer, D.A., eds., Mineral deposit models: U.S. Geological Survey Bulletin 1693, p. 162-164.

Mosier, D.L., 1986j, Grade and tonnage model of warm-current type phosphate deposits, in Cox, D.P., and Singer, D.A., eds., Mineral deposit models: U.S. Geological Survey Bulletin 1693, p. 237-238.

Mosier, D.L., 1986k, Grade and tonnage model of Zn-Pb skarn deposits, in Cox, D.P., and Singer, D.A., eds., Mineral deposit models: U.S. Geological Survey Bulletin 1693, p. 90-93.

Mosier, D.L., and Briskey, J.A., 1986, Grade and tonnage model of southeast Missouri Pb-Zn and Appalachian Zn deposits, in Cox, D.P., and Singer, D.A., eds., Mineral deposit models: U.S. Geological Survey Bulletin 1693, p. 224-226.

Mosier, D.L., and Menzie, W.D., 1986, Grade and tonnage model of Fe skarn deposits, in Cox, D.P., and Singer, D.A., eds., Mineral deposit models: U.S. Geological Survey Bulletin 1693, p. 94-97.

Mosier, D.L., Morris, H.T., and Singer, D.A., 1986, Grade and tonnage model of polymetallic replacement deposits, in Cox, D.P., and Singer, D.A., eds., Mineral deposit models: U.S. Geological Survey Bulletin 1693, p. 101-104.

Mosier, D.L., and Page, N.J, 1988, Descriptive and grade-tonnage models of volcanogenic manganese deposits in oceanic environments-A modification: U.S. Geological Survey Bulletin 1811, 28 p. (Also available at $h t t p: / / p u b s . u s g s . g o v / b u l / b 1811 / b 1811 . p d f$.

Mosier, D.L., and Sato, Takeo, 1986, Grade and tonnage model of Sado epithermal veins, in Cox, D.P., and Singer, D.A., eds., Mineral deposit models, U.S. Geological Survey Bulletin 1693, p. 155-157.

Mosier, D.L., Sato, Takeo, and Singer, D.A., 1986, Grade and tonnage model of Creede epithermal veins, in Cox, D.P., and Singer, D.A., eds., Mineral deposit models: U.S. Geological Survey Bulletin 1693 , p. 146-149.

Mosier, D.L., and Singer, D.A., 1986, Grade and tonnage model of Superior Fe and Algoma Fe deposits, in Cox, D.P., and Singer, D.A., eds., Mineral deposit models: U.S. Geological Survey Bulletin 1693, p. 228-230.

Mosier, D.L., Singer, D.A., Bagby, W.C., and Menzie, W.D., 1992, Grade and tonnage model of sediment-hosted Au, in Bliss, J.D., ed., Developments in mineral deposit modeling: U.S. Geological Survey Bulletin 2004, p. 26-28.

Mosier, D.L., Singer, D.A., and Berger, B.R., 1986, Grade and tonnage model of Comstock epithermal veins, in Cox, D.P., and Singer, D.A., eds., Mineral deposit models: U.S. Geological Survey Bulletin 1693, p. 151-153.

Orris, G.J., 1992a, Grade and tonnage model of bedded barite, in Orris, G.J., and Bliss, J.D., eds., Industrial minerals deposit models - Grade and tonnage models: U.S. Geological Survey Open-File Report 92-437, p. 40-42. (Also available at http://pubs.usgs.gov/of/1992/ofr-92-0437/.)

Orris, G.J., 1992b, Grade and tonnage model of oolitic ironstones, in Bliss, J.D., ed., Developments in mineral deposit modeling: U.S. Geological Survey Bulletin 2004, p. 41-43. 
Orris, G.J., 1992c, Grade and tonnage model of serpentine-hosted asbestos, in Orris, G.J., and Bliss, J.D., eds., Industrial minerals deposit models - Grade and tonnage models: U.S. Geological Survey Open-File Report 92-437, p. 2-4. (Also available at http://pubs.usgs.gov/of/1992/ofr-92-0437/.)

Orris, G.J., 1992d, Preliminary grade and tonnage model of lacustrine borates, in Orris, G.J., and Bliss, J.D., eds., Industrial minerals deposit models - Grade and tonnage models: U.S. Geological Survey Open-File Report 92-437, p. 56-59. (Also available at http://pubs.usgs.gov/of/1992/ofr-92-0437/.)

Orris, G.J., 1992e, Preliminary grade and tonnage models of marine bedded gypsum, in Orris, G.J., and Bliss, J.D., eds., Industrial minerals deposit models - Grade and tonnage models: U.S. Geological Survey Open-File Report 92-437, p. 53-55. (Also available at http://pubs.usgs.gov/of/1992/ofr-920437/.)

Orris, G.J., and Bliss, J.D., 1986, Grade and tonnage model of placer Au-PGE, in Cox, D.P., and Singer, D.A., eds., Mineral deposit models: U.S. Geological Survey Bulletin 1693, p. 261-264.

Root, D.H., Menzie, W.D., and Scott, W.A., 1992, Computer Monte Carlo simulation in quantitative resource estimation: Nonrenewable Resources, v. 1, no. 2, p. 125-138.

Root, D.H., Scott, W.A., Jr., and Selner, G.I., 1996, Computer program for aggregation of probabilistic assessments of mineral resources: U.S. Geological Survey Open-File Report 96-94, 1 diskette.

Rytuba, J.J., 1986, Grade and tonnage model of hot-spring Hg, in Cox, D.P., and Singer, D.A., eds., Mineral deposit models: U.S. Geological Survey Bulletin 1693, p. 178-179.

Rytuba, J.J., and Cargill, S.M., 1986, Grade and tonnage model of silica-carbonate Hg, in Cox, D.P., and Singer, D.A., eds., Mineral deposit models: U.S. Geological Survey Bulletin 1693, p. 181-182.

Singer, D.A., 1986a, Grade and tonnage model of Besshi massive sulfide, in Cox, D.P., and Singer,

D.A., eds., Mineral deposit models: U.S. Geological Survey Bulletin 1693, p. 136-138.

Singer, D.A., 1986b, Grade and tonnage model of lateritic Ni, in Cox, D.P., and Singer, D.A., eds., Mineral deposit models: U.S. Geological Survey Bulletin 1693, p. 252-254.

Singer, D.A., 1992, Grade and tonnage model of Sierran kuroko deposits, in Bliss, J.D., ed., Developments in mineral deposit modeling: U.S. Geological Survey Bulletin 2004, p. 29-32.

Singer, D.A., 1998, Revised grade and tonnage model of carbonatite deposits: U.S. Geological Survey Open-File Report 98-235, 7 p.

Singer, D.A., Berger, V.I., and Moring, B.C., 2005, Porphyry copper deposits of the world—Database, map, and grade and tonnage models: U.S. Geological Survey Open-File Report 2005-1060, 9 p. and data files, available only online at http://pubs.usgs.gov/of/2005/1060/. (Superseded by USGS OpenFile Report 2008-1155.)

Singer, D.A., Berger, V.I., and Moring, B.C., 2008, Porphyry copper deposits of the world-Database and grade and tonnage models, 2008: U.S. Geological Survey Open-File Report 2008-1155, 45 p. and data files, available only online at http://pubs.usgs.gov/of/2008/1155/.

Singer, D.A., Briskey, J.A., and Cunningham, C.G., 2008, Grade and tonnage model of giant porphyry copper deposits, Appendix 1 of Cunningham, C.G., and others, Quantitative mineral resource assessment of copper, molybdenum, gold, and silver in undiscovered porphyry copper deposits in the Andes Mountains of South America: U.S. Geological Survey Open-File Report 2008-1253, p. 64-67, available on CD-ROM and at http://pubs.usgs.gov/of/2008/1253/.

Singer, D.A., and Menzie, W.D., 2010, Quantitative mineral resource assessments-An integrated approach: New York, Oxford University Press, 219 p.

Singer, D.A., and Mosier, D.L., 1986a, Grade and tonnage model of Cyprus massive sulfide, in Cox, D.P., and Singer, D.A., eds., Mineral deposit models: U.S. Geological Survey Bulletin 1693, p. 131135. 
Singer, D.A., and Mosier, D.L., 1986b, Grade and tonnage model of kuroko massive sulfide, in Cox, D.P., and Singer, D.A., eds., Mineral deposit models: U.S. Geological Survey Bulletin 1693, p. 190197.

Singer, D.A., and Mosier, D.L., 1986c, Grade and tonnage model of rhyolite-hosted Sn, in Cox, D.P., and Singer, D.A., eds., Mineral deposit models: U.S. Geological Survey Bulletin 1693, p. 169-171.

Singer, D.A., Mosier, D.L., and Menzie, W.D., 1993, Digital grade and tonnage data for 50 types of mineral deposits: U.S. Geological Survey Open-File Report 93-280, version 1.0, on CD-ROM. (Also available at http://pubs.usgs.gov/of/1993/ofr-93-0280/.)

Singer, D.A., and Page, N.J, 1986a, Grade and tonnage model of dunitic Ni-Cu, in Cox, D.P., and Singer, D.A., eds., Mineral deposit models: U.S. Geological Survey Bulletin 1693, p. 24-27.

Singer, D.A., and Page, N.J, 1986b, Grade and tonnage model of minor podiform chromite, in Cox, D.P., and Singer, D.A., eds., Mineral deposit models: U.S. Geological Survey Bulletin 1693, p. 3438.

Singer, D.A, and Page, N.J, 1986c, Grade and tonnage model of placer PGE-Au, in Cox, D.P., and Singer, D.A., eds., Mineral deposit models: U.S. Geological Survey Bulletin 1693, p. 265-269.

Singer, D.A., Page, N.J, and Lipin, B.R., 1986, Grade and tonnage model of major podiform chromite, in Cox, D.P., and Singer, D.A., eds., Mineral deposit models: U.S. Geological Survey Bulletin 1693, p. $38-44$.

Singer, D.A., Page, N.J, and Menzie, W.D., 1986a, Grade and tonnage model of komatiitic Ni-Cu, in Cox, D.P., and Singer, D.A., eds., Mineral deposit models: U.S. Geological Survey Bulletin 1693, p. $18-23$.

Singer, D.A., Page, N.J, and Menzie, W.D., 1986b, Grade and tonnage model of synorogenicsynvolcanic Ni-Cu, in Cox, D.P., and Singer, D.A., eds., Mineral deposit models: U.S. Geological Survey Bulletin 1693, p. 28-31.

Singer, D.A., Theodore, T.G., and Mosier, D.L., 1986, Grade and tonnage model of Climax Mo deposits, in Cox, D.P., and Singer, D.A., eds., Mineral deposit models: U.S. Geological Survey Bulletin 1693, p. 73-75.

Sutphin, D.M., and Bliss, J.D., 1990, Disseminated flake graphite and amorphous graphite deposit types-An analysis using grade and tonnage models: CIM Bulletin, v. 83, no. 940, p. 85-89. 